\%

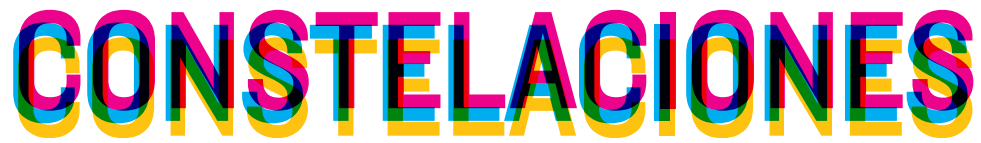

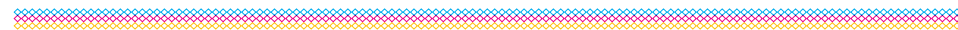


CONSTELACIONES n², mayo 2014

Revista de Arquitectura de la Universidad CEU San Pablo

Architecture Magazine of CEU San Pablo University

Periodicidad anual

Annual periodicity

COMITÉ DE REDACCIÓN EDITORIAL COMMITTEE

\section{Director Director}

Juan García Millán

Jefa de Redacción Editor in Chief

Covadonga Lorenzo Cueva

Secretario de Redacción Editorial Clerk

Rodrigo Núñez Carrasco

Maquetación y producción Design and production

María Fernández Hernández

Vocales Board Members

Fernando del Ama Gonzalo. Escuela Politécnica Superior, Universidad CEU San Pablo, Madrid

Pablo Campos Calvo-Sotelo. Escuela Politécnica Superior, Universidad CEU San Pablo, Madrid

Alfonso Díaz Segura Escuela Superior de Enseñanzas Técnicas, Universidad CEU Cardenal Herrera, Valencia

Mayka García Hípola. Escuela Politécnica Superior, Universidad CEU San Pablo, Madrid

Sonia Izquierdo Esteban. Escuela Politécnica Superior, Universidad CEU San Pablo, Madrid

Javier Sáenz Guerra. Escuela Politécnica Superior, Universidad CEU San Pablo, Madrid

\section{CONSEJO EDITORIAL EDITORIAL BOARD}

Beatriz Colomina. School of Architecture, Princeton University, New Jersey

Carmen Díez Medina. Escuela de Ingeniería y Arquitectura, Universidad de Zaragoza

María Antonia Frías Sargadoy. Escuela Técnica Superior de Arquitectura, Universidad de Navarra

Ángel González García. Facultad de Geografía e Historia, Universidad Complutense de Madrid

Juan Miguel Hernández Léon. Escuela Técnica Superior de Arquitectura, Universidad Politécnica de Madrid

Juan José Lahuerta Alsina. Escuela Técnica Superior de Arquitectura, Universidad Politécnica de Cataluña, Barcelona

Eduardo Leira Sánchez. Ex director del Plan General de Ordenación Urbana, Madrid

Joaquín Medina Wamburg. Facultad de Aquitectura Diseño y Urbanismo, Universidad de Buenos Aires

Zaida Muxí Martínez. Escuela Técnica Superior de Arquitectura, Universidad Politécnica de Cataluña, Barcelona

José Joaquín Parra Bañón. Escuela Técnica Superior de Arquitectura, Universidad de Sevilla

Víctor Pérez Escolano. Escuela Técnica Superior de Arquitectura, Universidad de Sevilla

Fernando Pérez Oyarzún. Escuela de Arquitectura y Diseño, Pontificia Universidad Católica, Santiago de Chile Judith Sheine. School of Architecture and Allied Arts, University of Oregon, Portland

Andrés Walliser Martínez. Global Design, New York University, Nueva York

\section{ISSN 2340-177X}

Depósito legal M-13872-2013

(c) de los textos, sus autores

(c) de las imágenes autorizadas

(c) Revista Constelaciones

๑) Escuela Politécnica Superior, Universidad CEU San Pablo

Universidad CEU San Pablo

Escuela Politécnica Superior

Urbanización Montepríncipe, $s / n$

Boadilla del Monte, 28668. Madrid (España)

constelaciones@eps.ceu.es

www.uspceu.es

Edición Edition

Fundación Universitaria San Pablo CEU

Madrid, España

Impresión Printing

VA Impresores

Impreso en España Printed in Spain

Distribución Distribution

CEU Ediciones

Los textos que componen Constelaciones se obtienen mediante convocatoria pública. Para que los trabajos recibidos entren en el proceso de selección de los artículos a publicar deben ser trabajos originales no publicados anteriormene, con una extensión recomendada de 3.000 palabras, título, resumen (un máximo de 150 palabras) y palabras clave (un mínimo de cuatro palabras), en español y en inglés. Tras haber cumplido estos requisitos (y los correspondientes incluidos en las normas editoriales de la revista, disponibles para consulta en formato digital desde el comienzo de la convocatoria), tiene lugar un proceso de revisión y evaluación de los artículos previa aceptación de los mismos para su publicación. Para acometer dicho proceso, y con el fin de asegurar la calidad de los contenidos, la Revista Constelaciones recurre a evaluadores externos a la institución editora y anónimos (cada artículo es evaluado por dos de ellos) encargados de someter a crítica los mismos. Todos los artículos de investigación publicados en esta revista han pasado por dicho proceso. La recepción de artículos se extendió hasta el 30 de Septiembre de 2013. Texts included in Constelaciones are obtained by public announcement. Only original papers that have not been previously published will be included in the process of selection of articles. They should not exceed 3.000 words and should include a title, an abstract (no more than 150 words) and keywords (a minimum of four words), in Spanish and English. After having fulfilled these requirements (and those included in magazine editorial standards, available for consultation from the beginning of the Call for Papers), occurs a process of review and evaluation of articles upon acceptance of them for publication. To undertake this process, and in order to ensure the quality of the contents, Constelaciones turns to external and anonymous evaluators to the institution (each article is evaluated by two of them) responsible for the critic. All the articles published in this journal have undergone this process. The deadline for reception was extended until September 30, 2013.

Todos los derechos reservados. Esta publicación no puede ser reproducida, ni en todo ni en parte, ni registrada, ni transmitida, ni almacenada en ningúna forma ni por ningún medio, sin la autorización previa y por escrito del equipo editorial. En este número se han utilizado algunas imágenes de las que no se ha podido identificar al propietario de los derechos. En estos casos hemos entendido que las imágenes son de libre uso. En caso de identificar alguna de estas imágenes como propia, por favor, póngase en contacto con la redacción de Constelaciones. Los criterios expuestos en los diversos artículos de la revista, son responsabilidad exclusiva de sus autores, y no reflejan necesariamente los que pueda tener el equipo editoral. El equipo editorial de la revista no se responsabiliza de devolver la información enviada a la redacción a no ser que se le solicite expresamente. All rights reserved. This publication cannot be reproduced, in whole or in part, nor registered, transmitted or stored in any form or by any means, without the written permission of the Editorial team, In this issue some images were used without knowing the owner of the rights. In these cases, we have understood that the images are free of use. In case you identify written permission of the Editorial team, In this issue some images were used without knowing the owner of the rights. In these cases, we have understood that the images are free of use. In case you identify
any of these images as your own, please, contact with the Editorial staff of Constelaciones. The opinions expressed in this issues's articles are entirely the responsibility of their authors and are not necessarily shared by the editors of this journal. The publisher don't take responsibility for returning submitted material which is not expressly requested. 


$$
11
$$




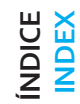

$\stackrel{n}{\sim}$

ร

5

$\curvearrowright$

๙ิ

$\stackrel{n}{=}$

$\bar{m}$
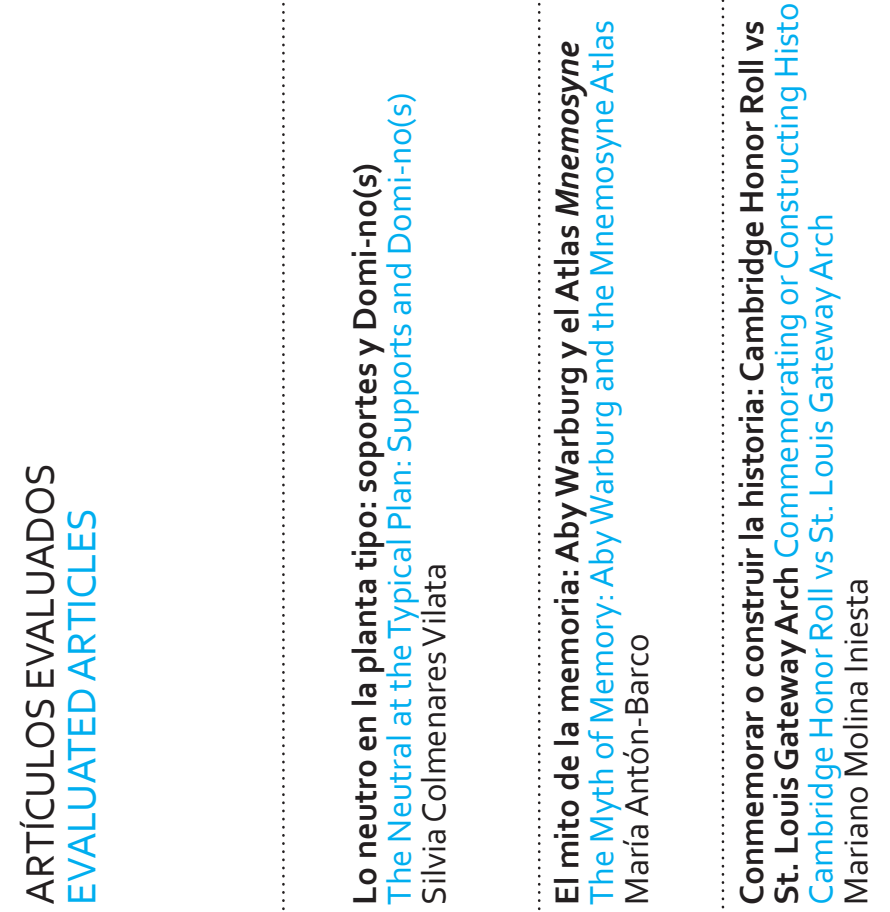

旁 을

‥

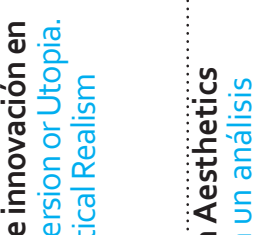

앙

胥苞

$\bar{\Psi}$

宛

일

능홍

区告

음 흠

응 흥

\%

든

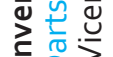

ข

음

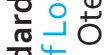

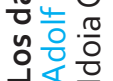

a व

은

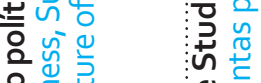

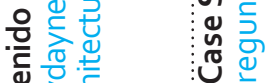

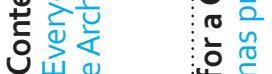

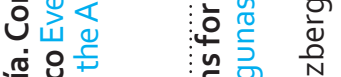

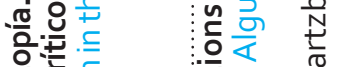

गे

गे० गे ये ज

:

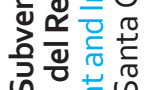

है

ज०

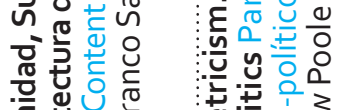

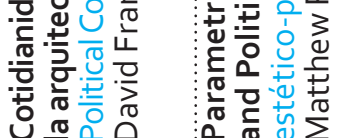

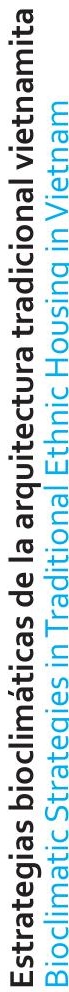

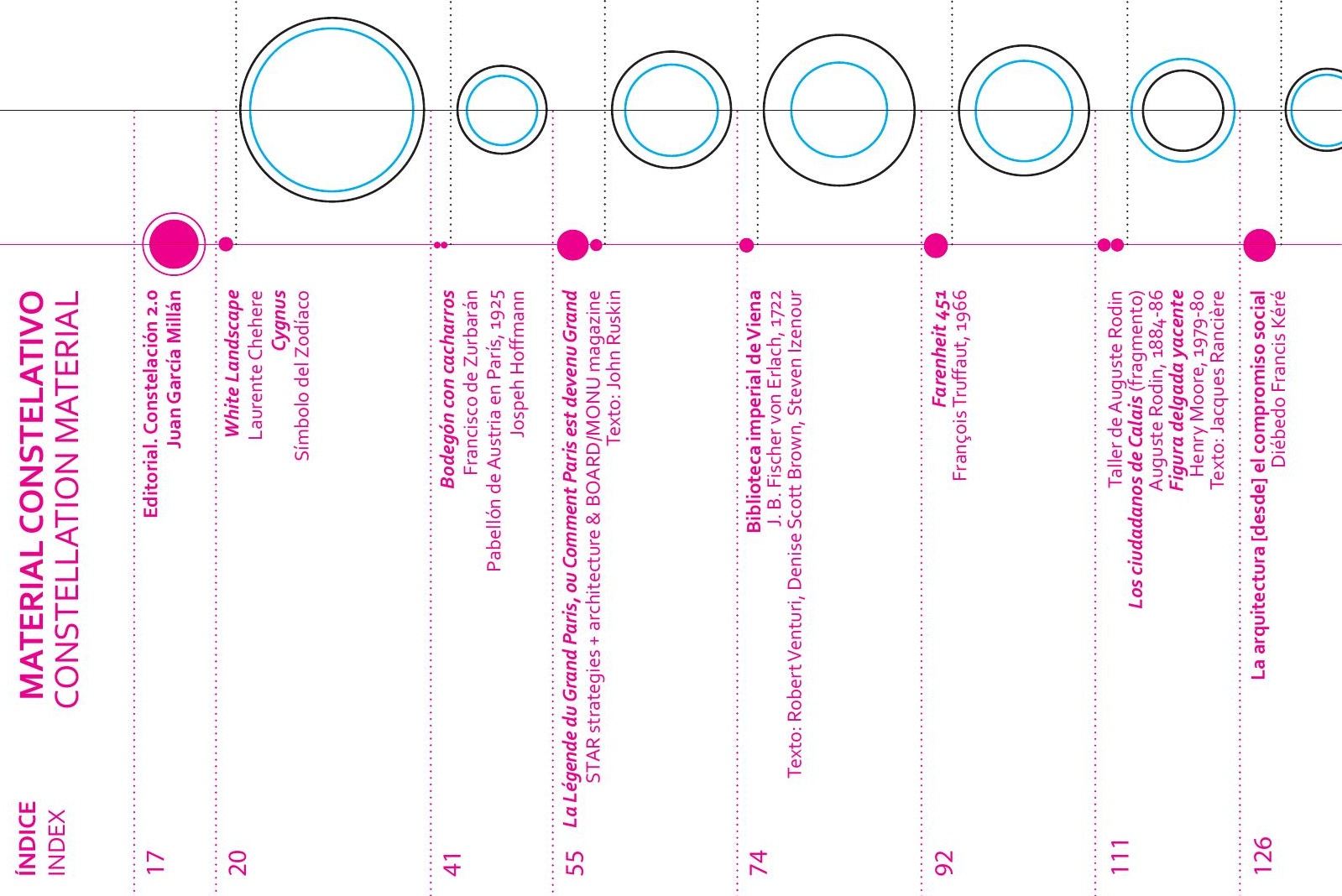

苍

० 


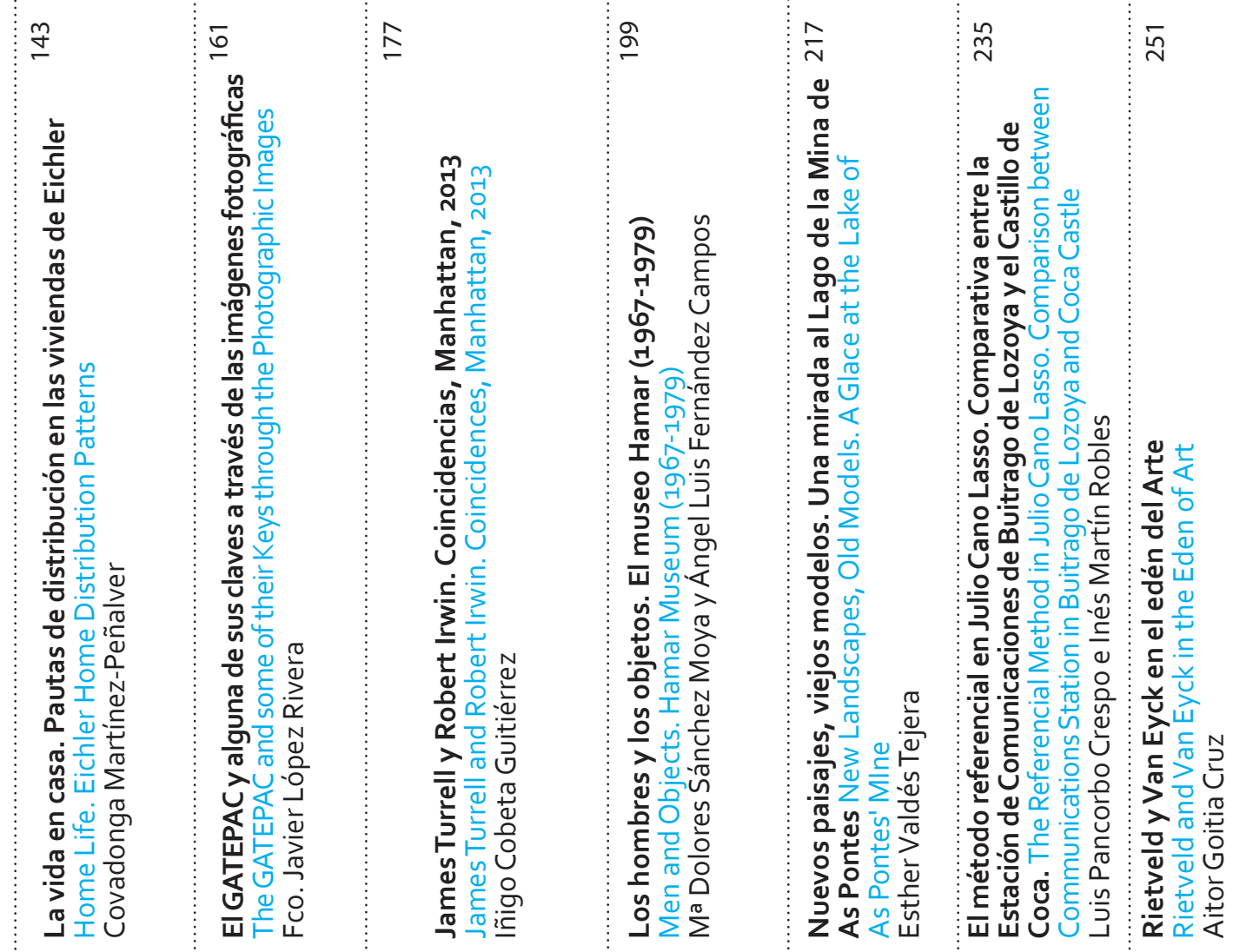
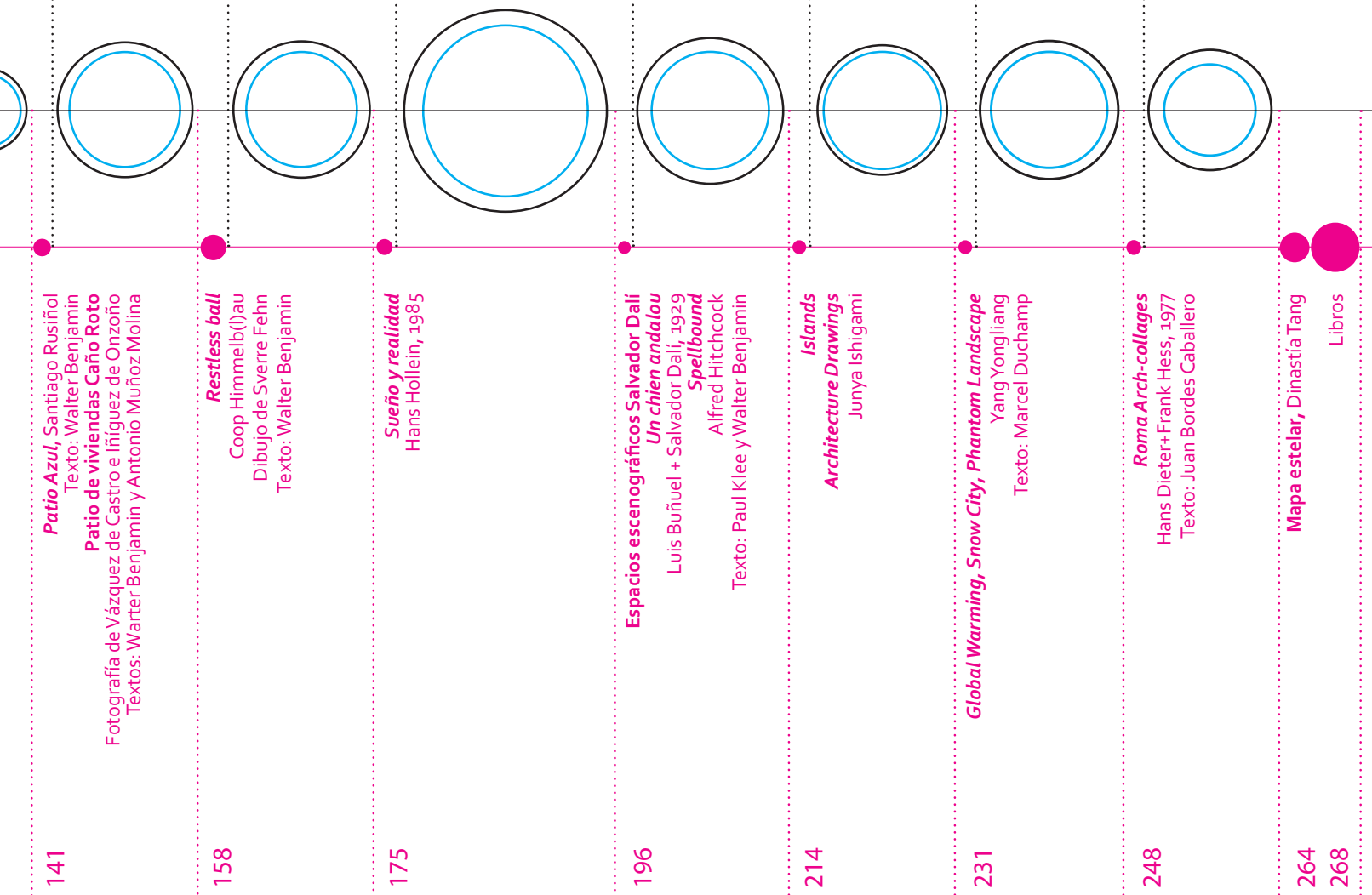

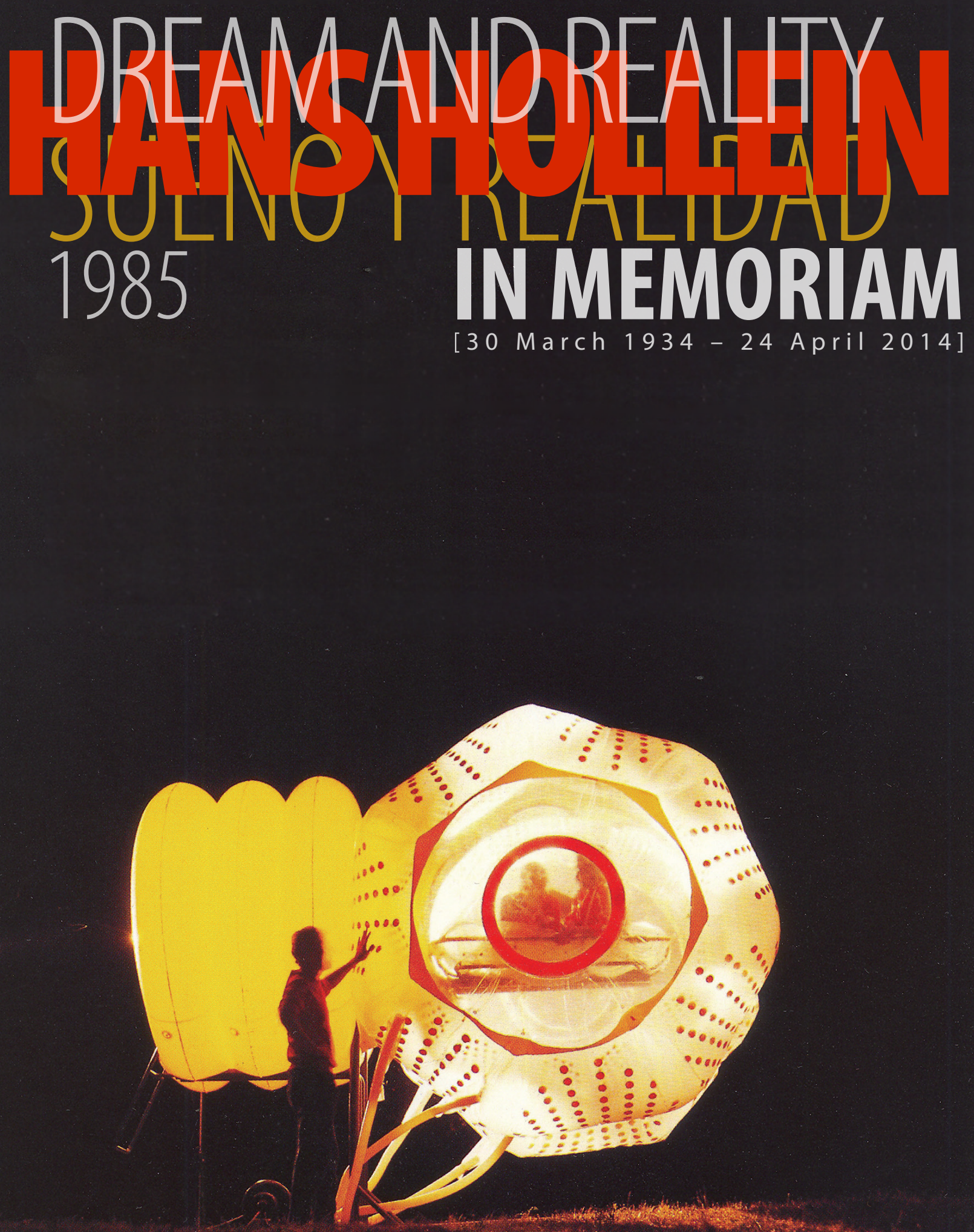


\section{James Turrell y Robert Irwin. Coincidencias, Manhattan, 2013 James Turrell and Robert Irwin. Coincidences, Manhattan, 2013}

\section{Î́igo Cobeta Gutiérrez}

Escuela Técnica Superior de Arquitectura, Universidad Politécnica, Madrid

Traducción Translation Iñigo Cobeta Gutiérrez, Yvonne Choy*

(*) El autor desea expresar su agradecimiento a Yvonne Choy por su ayuda y hospitalidad.

\section{Palabras clave Keywords}

James Turrell, Robert Irwin, Guggenheim Museum, Withney Museum, percepción espacial, umbral, espacios sensoriales James Turrell, Robert Irwin, Guggenheim Museum, Withney Museum, spatial perception, threshold, sensing spaces

\section{Resumen}

Durante el verano de 2013 Manhattan albergó las muestras de dos artistas que trabajan con la luz y el espacio: una amplia exposición retrospectiva de James Turrell en el Museo Guggenheim y una instalación de Robert Irwin para el Museo Withney de Arte Americano. Ambos han hecho de la percepción el elemento fundamental de sus obras en una investigación que comenzó en los años sesenta y que han continuado desarrollando a lo largo de los últimos cuarenta y cinco años. Los dos compartieron en sus comienzos una línea de investigación conjunta, sus investigaciones sobre las sensaciones en el espacio y su estudio empírico fueron cruciales para el desarrollo de sus obras que hacen de la experiencia espacial un mecanismo de trascendencia. Sus trabajos son de gran interés para la arquitectura porque los dos hacen de la percepción en el espacio el argumento fundamental de su investigación artística.

\section{Abstract}

During the summer of 2013 Manhattan hosted two shows by a couple of artists who work with light and space: a retrospective exhibition by James Turrell at the Guggenheim Museum and an installation by Robert Irwin for the Whitney Museum of American Art. Both artists have made perception the main element of their works in an investigation which has continued over forty five years. They both shared in their beginnings a common ground investigation in sensing space and its empirical study were crucial towards the development of a body of work that makes the experience of space a transcendental mechanism. Their precepts are of great interest for architecture as they both make perception within space the main issue of their artistic investigation. 
Durante el verano de 2013 han coincidido en Manhattan una gran exposición antológica de James Turrell, que ocupó prácticamente todo el Museo Guggenheim y la recuperación de una obra emblemática de Robert Irwin, concebida en 1977 para la retrospectiva que le dedicó entonces el Museo Withney de Arte Americano. La relación entre ambas propuestas nos remite a un lugar conceptual común que se fraguó en parte durante la segunda mitad de los años sesenta en la costa californiana, cuando ambos artistas formaban parte del entonces incipiente movimiento Light and Space. Las coincidencias entre ambas posturas y su vínculo con la luz en el espacio hacen de ellas un interesante objeto de reflexión para la arquitectura.

James Turrell en el Museo Guggenheim. Entre el 21 junio y el 25 de septiembre el Museo Solomon R. Guggenheim de Nueva York albergó una exposición antológica de James Turrell comisariada por Carmen Giménez y Nat Trotman. Fue su primera gran retrospectiva en la ciudad desde 1980 y coincidió con otras dos muestras simultáneas en el Museo de Bellas Artes de Houston y en el LACMA. La muestra abarcaba un periodo de casi medio siglo, durante el cual Turrell ha conseguido desarrollar un lenguaje en el que la aparente materialización de la luz y su percepción constituyen el sujeto central de la experiencia artística. Llama la atención lo escueto de la muestra, que sin embargo ocupa la mayor parte del edificio. Mucho del espacio expositivo habitual permanece vacío. El gran hueco central del museo concebido por Frank Lloyd Wright y terminado en 1959 alberga una espectacular obra realizada ex profeso para la ocasión.

Comenzando la visita desde arriba, la primera sala de la planta superior está en penumbra. Unos grabados hábilmente iluminados parecen emanar luz. Cuesta habituar el ojo a la intensidad de la contraposición luz-sombra, blanco-negro. A medida que la retina se habitúa comienzan a captarse los matices, antes imperceptibles a primera vista. Tenues contrastes componen sombras en el seno de la oscuridad y se insinúan sutilísimas aristas en la luz. No se sabe si ésta va a los grabados o sale de su compleja textura. Son las aguatintas (1) de la serie First Light de 1989-1990. (Fig. 1)

During the summer of 2013 a great anthological exhibition on James Turrell which occupied almost the entire Guggenheim Museum in New York City and the reinstallation of an emblematic work by Robert Irwin made in 1977 for the retrospective on the artist that the Whitney Museum of American Art then held coincided in Manhattan. The relation between both proposals sets us on a common conceptual ground which was partly forged during the second half of the sixties when both artists took part in the then incipient movements of Light and Space. The coincidences between both proposals including their bond of light in the space make them an interesting and relative issue for architecture.

James Turrell in the Guggenheim Museum. Between June 21st and September 25th the Solomon R. Guggenheim Museum of New York held a James Turrell anthological exhibition curated by Carmen Giménez and Nat Trotman. It was his first major retrospective in the city since 1980 and it was coincident with two other simultaneous exhibits at the Houston Fine Arts Museum and the Los Angeles County Museum of Art. The show covered a period of nearly half a century during which James Turrell managed to develop a language in which the apparent materialization of light and its perception became the main subject of the artistic experience. It is surprising how concise the exhibit is despite occupying most of the building. The grand central core; the void of the Museum conceived by Frank Lloyd Wright and finished in 1959 hosted a spectacular work specifically mounted for the occasion. 


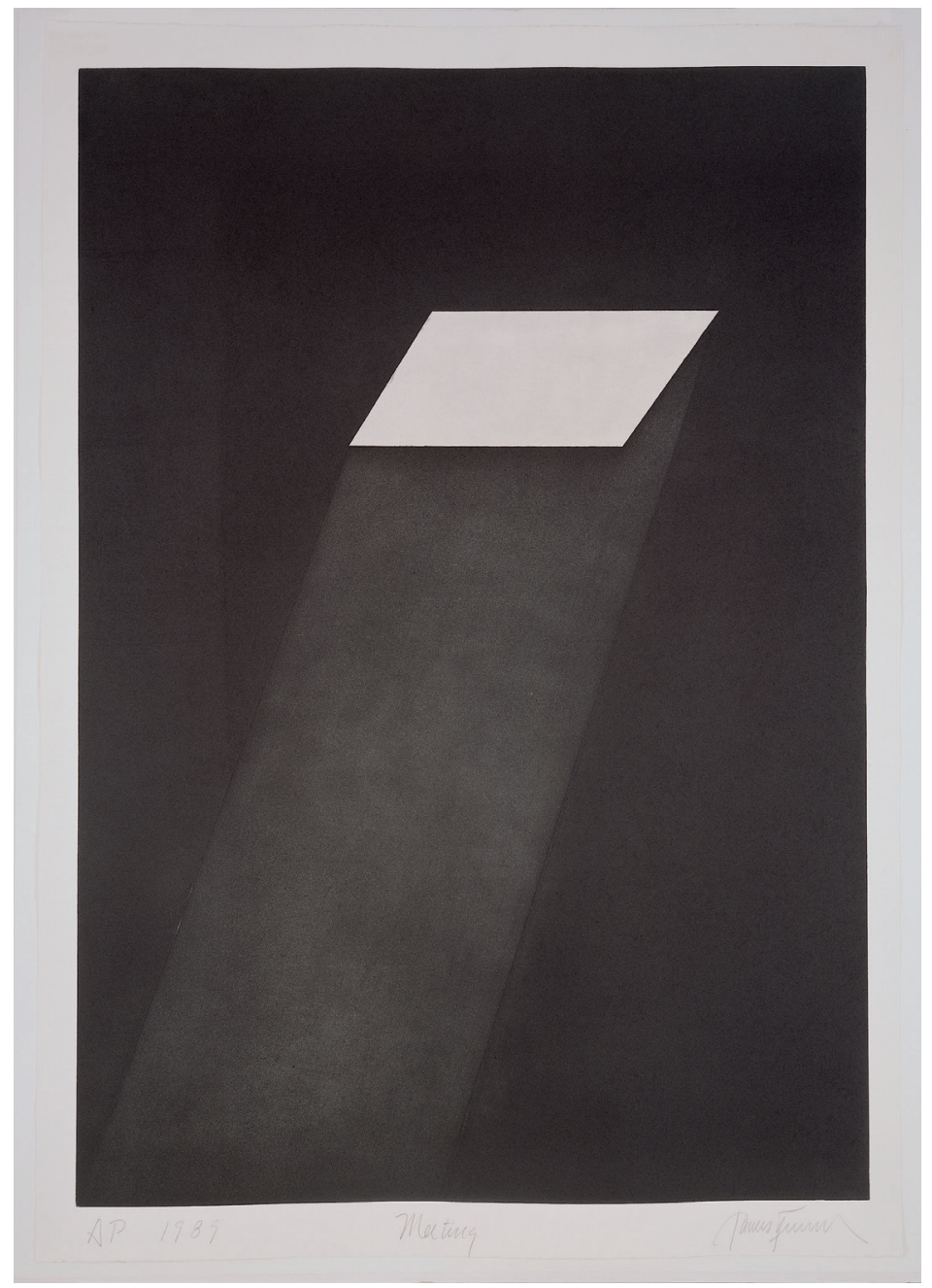

Fig. 1. Turrell, James: Meeting (del portfolio First Light), 1989-90. Aguatinta, 108 x 75.6 cm. ( ) James Turrell. Fotografía: Peter Blum Edition, Nueva York.

Starting the visit in the upper floor the first room is dimly lit. Some etchings (1) skillfully lightened seem to emanate light. It required some effort to get the eye adjusted to the contrast between light and dark, white and black. As the retina adapts, we start to appreciate the nuances before inapprehensible upon first sight. Slight contrasts build up shadows in the bosom of the darkness and extremely subtle edges can be intuited in the light. We can't tell if it goes to the etchings or if it comes from its complex texture. This seductive glow then reveals itself as the aquatints of the First Light series from 1989-90. (Fig. 1)

Afterwards, within the same shadow the space becomes cooler due to the xenon lights which project their long beams across the room and against the walls. Two contiguous rooms host the oldest works of the exhibition which extend all the way back to 1966 when Turrell started experimenting with light projections (Fig. 2) in the rented rooms of the Mendota Hotel (Fig. 3) of Ocean Park in Santa Monica.

During several years Turrell transformed the rooms of the hotel experimenting with luminous effects to capture and refine the techniques which lead to the thresholds of space perception and the modeling of light. As Turrell states it was a long process because of dealing with an intangible substance which is transformed by its container but over which you can't directly operate (Turrell, 1992). The works were suspended at the beginning of the eighties when the building was purchased 


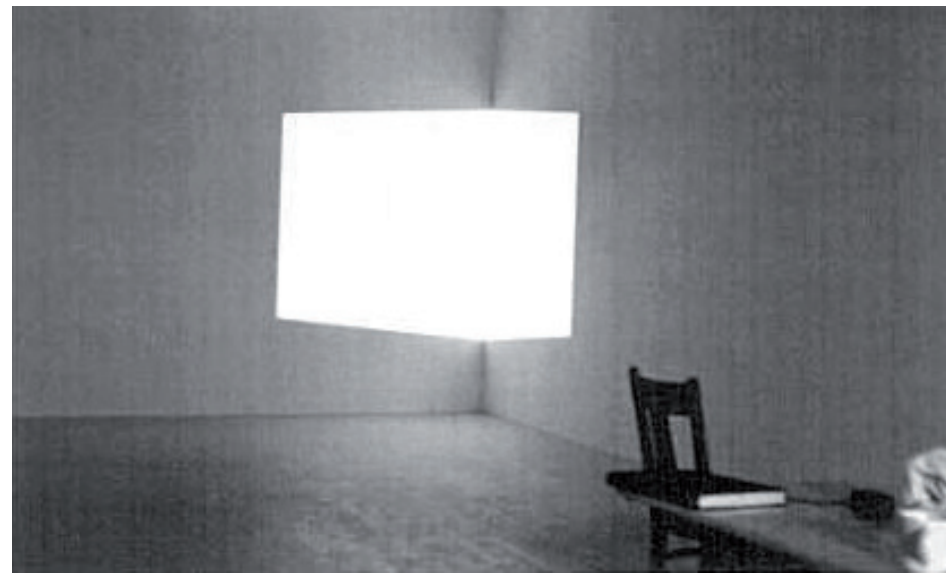

A continuación, dentro de la misma penumbra la luz adquiere una cualidad más fría debido a los focos de xenón que proyectan haces contra las paredes. Dos salas contiguas albergan las obras más antiguas de la exposición, que se remontan a 1966 cuando Turrell comenzó a trabajar con proyecciones de luz (Fig. 2) en las habitaciones del Mendota Hotel (Fig. 3) de Ocean Park en Santa Mónica.

Durante varios años Turrell transformó las habitaciones del hotel, experimentando con los efectos lumínicos para familiarizarse con las técnicas que llevan a los umbrales de la percepción espacial y el modelado de la luz. Fue un largo proceso debido a que se trata una sustancia intangible que es transformada por lo que la contiene, pero sobre la que no se puede operar directamente (Turrell, 1992). El trabajo tuvo que ser suspendido a principios de los ochenta, cuando el edificio pasó a manos de un grupo de inversores que le cancelaron el alquiler. Este cambio supuso perder, no sólo el estudio sino también su principal espacio expositivo, que durante más de quince años le había proporcionado una gran independencia y control sobre su obra. Abandonó California y se mudó a Flagstaff en Arizona, junto al Roden Cra-

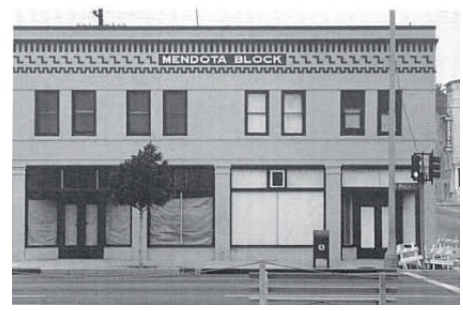

Fig. 2. Afrum-Proto, 1966. Proyección halógeno-cuarzo, instalación en el estudio del Hotel Mendota, Ocean Park, California, 1968. Colección de Edward y Melinda Wortz, Pasadena. Fotografía: James Turrell.

Fig. 3. Hotel Mendota, Ocean Park, California, 1970-1972. Fotografía: James Turrell.

by a investors who cancelled the rental. He not only lost the studio but also the exhibition space which for over fifteen years had proportioned him a great deal of independence and control over his work. He left California and moved to Flagstaff in Arizona nearby the Roden Crater. There he has continued building since 1979 a project conceived in 1976 that is for certain to be his magnum opus.

The work Prado (White) (Fig. 4) is in the first of the two rooms. It is a horizontal light rectangle apparently posed vertically on the edge of the floor. The intensity of the light seems to drill the wall generating a space beyond it. In the second space a playful light cube seems to float suspended attached to the corner of the room. It is like a phantom volume. As we move around the room, the cube seems to deform slightly, itself following us to and fro. If we get closer the cube becomes light and the illusion vanishes. This is the work Afrum (White) (Fig. 5) The Projection Pieces, the series of which both belong, were the first works of a Turrell solo exhibition held at the Pasadena Museum of Art in 1967. They are also the drawn subject on the First Light aquatints we just saw.

As we step into Iltar (1976) (Figs. 6, 7) the impression is intense because of the abrupt darkness. Upon entering, we hardly see anything, after the perceptual transition, the essence of the work, occurs. Slowly as our retinas recalibrate we start seeing 
ter, para desarrollar un proyecto concebido en 1976, que comenzó en 1979 y en el que trabaja desde entonces construyendo su obra maestra.

La obra Prado (White), (Fig. 4) ubicada en la primera de las dos salas, consiste en un rectángulo de luz apaisado aparentemente apoyado en vertical a ras de suelo. La potencia de la luz proyectada contra el muro parece atravesarlo, generando un espacio más allá de él. En el segundo espacio, un cubo de luz parece flotar suspendido en la diagonal opuesta al acceso. Aparece un volumen fantasma. Según nos movemos, el cubo aparenta deformarse ligeramente siguiéndonos. Si nos acercamos el cubo, se convierte en luz y la ilusión se desvanece. Es la obra Afrum I (White). (Fig. 5) Las Projection Pieces, serie a la que pertenecen ambas obras, conformaron la primera exposición de Turrell en el Pasadena Museum of Art, en 1967, y son además el motivo representado en la serie de grabados First Light que acabamos de ver.

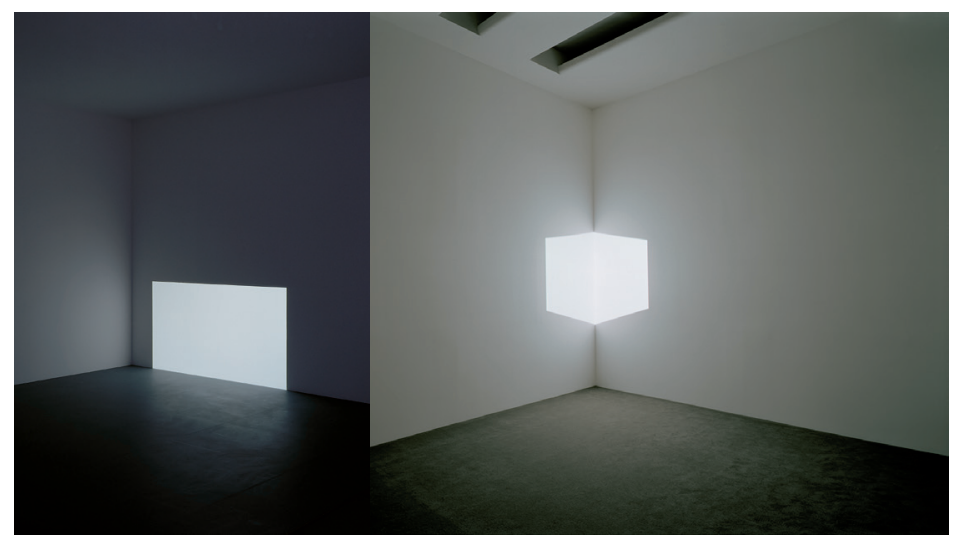

Fig. 4. Turrell, James: Prado (White), 1967. Luz proyectada, dimension variable. Colección Kyung-Lim Lee Turrell. @ James Turrell. Fotografía: Florian Holzherr.

Fig. 5. Turrell, James: Afrum I (White), 1967. Luz proyectada, dimension variable. Solomon R. Guggenheim Museum, New York, Panza Collection. () James Turrell. Instalación: Singular Forms (sometimes repeated), Solomon R. Guggenheim Museum, Nueva York, 5 marzo-19 mayo, 2004. Fotografía: David Heald. @ Solomon R. Guggenheim Foundation, Nueva York.

again and the room appears. We see two dim spotlights and after them a rectangle on the wall. The perception of the shape is delayed. As the eye gets accustomed to the environment, we start to sense the deepness of the space within the rectangle, a second darkness within the previous, manifests itself. In Prado (White) the substance was light; here we sense the darkness within the void.

This work belongs to the Space Division Construction series and it is at this exhibition combined with the Dark Spaces series. Turrell shows the space divided in two rooms: one of them is the sensing space from which we perceive or feel a space sensible to the events that take place out of it (Turrell, 1992). The other holds the event. Both were communicated by a rectangular shape where the dividing wall and the space behind it seemed to be on the same surface. This flat effect of space coincidence built by apparently eliminating the thickness of the frame has been frequently used by Turrell. By flattening the wall and the space beyond creates an optical illusion where the deepness of an apparently flat animated surface generates an uneasy feeling. This effect occurs in the Skyspaces. (2)

The optical phenomena Turrell deals with have been known for ages. The flat appearance of his windows reminds us of the projections within the interior of a camera obscura and the slow adaptation of the retina is what happens any summer day when 
Al entrar en la siguiente obra, Iltar, de 1976 (Figs. 6, 7), la impresión es intensa debido a la oscuridad. Al principio apenas vemos nada, después se va produciendo la transición perceptiva que constituye su esencia. Lentamente se activa la vista y va apareciendo una habitación con dos tenues focos, tras los cuales se intuye un rectángulo más oscuro que parece adosado al muro. La percepción de la forma se demora. A medida que la retina se habitúa comienza a intuirse la profundidad del espacio que alberga el rectángulo, una segunda oscuridad dentro de la anterior se va desvelando. En la obra Prado (White) la sustancia era la luz, aquí lo es la sombra albergada tras el hueco. En la serie Space Division Constructions a la que pertenece la obra, y que aquí se combina con la oscuridad (serie Dark Spaces), Turrell presentaba el espacio dividido en dos habitaciones: una de ellas denominada Sensing Space constituía el espacio desde el que percibir o sentir, un espacio sensible a los acontecimientos que tienen lugar fuera de él (Turrell, 1992). La otra alberga el fenómeno. Ambos estaban comunicados por un marco rectangular, donde el muro de separación y el espacio tras él parecen compartir el mismo

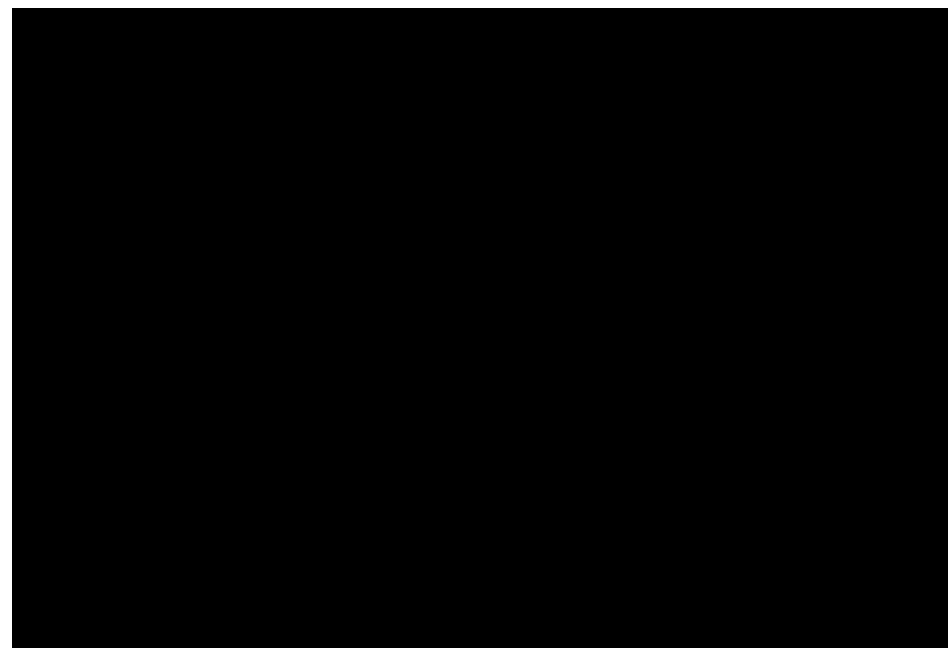

Fig. 6. Turrell, James. Iltar, 1976. Luz tungsteno, dimension variable. Solomon R. Guggenheim Museum, New York, Panza Collection. (C) James Turrell.

Fig. 7. Turrell, James: Iltar, University of Arizona Museum of Art, Tucson, 5 septiembre-12 octubre, 1980. Fotografía: James Turrell.

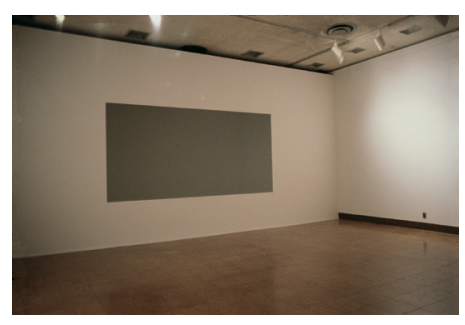

stepping into a dark space. But Turrell isolates these effects through formal abstractions and recomposes them in series with variations that generate intense sensations in the thresholds of perception. He takes the perceiver's experience to the limits of the physical capability to process the stimuli. The succession of the perceived experiences generates a certain state of hyperesthesia and the desolate ramp of the museum resonates with the rest of the works as if the emptiness was another work in and of itself. The spatial experience heightens and the container reanimates itself, gaining a more intense presence. Time also seems to be affected, it dilates.

Ronin (Fig. 8) is the penultimate piece. A vertical gap runs the full height in one of the alcoves partway up the ramp. It hosts a space to look into apparently amorphous and intriguing whose shape cannot be determined as it has no edges or elements of reference within it. As in Iltar we look into an apparent void, but by distinction this one does not hide in the dark. These kinds of spaces are highly disturbing. The work was firstly exhibited at the Stedelijk Museum despite having been previously rehearsed at the Mendota Hotel around 1967 shortly after developing the Projection Pieces.

Turrell explains how shapeless form doesn't allow any apprehension of color and produces states of imbalance (Turrell, 1992). So happened with the City of Ahirit installation conceived in 1976 for the Steidelijk Museum exhibit and also 
plano. Este efecto de concurrencia plana logrado mediante la eliminación del espesor aparente del marco es empleado por James Turrell a menudo. Al congregar el fondo y el muro, se produce la ilusión óptica de un plano animado en el que la profundidad produce un efecto discordante. Esto es especialmente patente en los Skyspaces. (2)

Los fenómenos ópticos que maneja Turrell son conocidos desde la antigüedad. La apariencia plana de los huecos recuerda a las proyecciones del interior de una cámara oscura y la paulatina adaptación de la retina a la oscuridad es lo que sucede un mediodía cualquiera de verano al entrar repentinamente en un espacio oscuro, pero él los aísla mediante la abstracción formal y los recompone en series y variaciones que generan intensas sensaciones en los umbrales de la percepción, al llevar la experiencia a los límites de la capacidad física del perceptor para procesar los estímulos. La sucesión de experiencias percibidas genera un cierto estado de hiperestesia en el que la despejada rampa del museo entra en resonancia con las obras como una más. La experiencia espacial se agudiza y el contenedor se anima cobrando una presencia más intensa. El tiempo también parece verse afectado, se dilata.

Ronin (Fig. 8) es la penúltima obra. Una grieta vertical abarca toda la altura de una de las salas en mitad de la rampa del museo. Alberga un espacio al que asomarse aparentemente informe y desconcertante cuya forma no se puede determinar al haber eliminado en él cualquier arista o elemento que pueda servir de referencia. Al igual que en la obra Iltar nos asomamos a un aparente vacío, aunque éste no se oculta en la oscuridad. Este tipo de espacios resultan profundamente desasosegantes. La obra que fue expuesta por primera vez en la exposición del Museo Stedelijk había sido ensayada anteriormente en el Hotel Mendota, más o menos alrededor de 1967, poco después de realizar las Projection Pieces.

Turrell explica cómo la ausencia de forma impide aprehender el color y se producen estados de desequilibrio (Turrell, 1992). Así sucedió con la instalación City of Ahirit, concebida en 1976 para la exposición en el Museo Stedelijk y expuesta durante su anterior retrospectiva en Nueva York, en

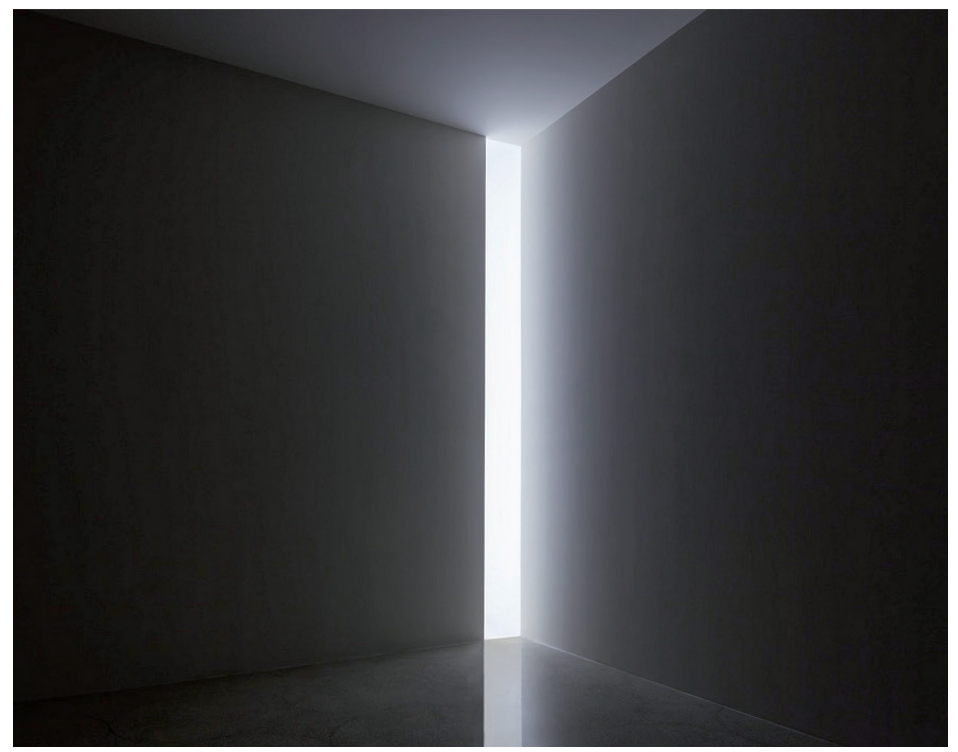

Fig. 8. Turrel, James: Ronin, 1968. Luz fluorescente, dimension variable. Colección del artista. ๑ James Turrell. Instalación: Jim Turrell, Stedelijk Museum, Amsterdam, 9 abril-23 mayo, 1976. Fotografía: Stedelijk Museum. 
1980, en el Museo Withney. El visitante se veía inmerso en un espacio donde la ausencia de forma aparente y los cambios de color hacían a la gente perder el equilibrio. Algunos acabaron andando a gatas y otros incluso se cayeron (Turrell, 1992). Esto se debía al efecto Ganzfeld, que se da cuando el sujeto está totalmente rodeado por un campo sensorial homogéneo (visual, acústico o táctil) y continuo que lo envuelve sin posibilidad de establecer elementos de referencia diferenciadores. El intento de la atención por comprender la forma y la imposibilidad de aprehender los límites del espacio acaban derivando en estados alterados de la percepción, análogos a los producidos por la privación sensorial. Un ejemplo sería tratar de escudriñar con la mirada en la oscuridad total. (3)

Al pie de la rampa desembocamos por fin en Aten Reign (Fig. 9) la obra más espectacular de la muestra, erigida específicamente para el espacio principal del edificio de Wright y que ocupa todo lo alto del gran vacío. Una sucesión de lo que parecen ser planos con huecos elípticos decrecientes en su centro, se van alejando hacia arriba. La imposibilidad de determinar la profundidad real de lo que estamos viendo produce un ligero estado de desazón, parecen planos pero no lo son (se trata de secciones cónicas). La obra activa los mecanismos perceptivos para entender el espacio pero la comprensión no encuentra acomodo en la forma, por lo que somos muy conscientes durante ese tiempo del esfuerzo de nuestra percepción y notamos cómo la mirada acecha.

Al desplazarnos alrededor de la elipse sentimos que el espacio parece mutar. (4) La reconstrucción mental se torna esquiva. La percepción pugna por comprender el artefacto suspendido sobre nuestras cabezas. Los aparentes planos cambian de color poco a poco graduados según su profundidad. Unas colchonetas instaladas justo debajo permiten disfrutar del espectáculo tumbado y se produce una sensación de ingravidez. James Turrell aísla mediante la abstracción el acontecimiento lumínico. Elimina todo aquello que le es ajeno y construye silencios en los que tomamos conciencia de nuestra propia mecánica sensitiva. Vemos la luz flotando en los espacios. Nos damos cuenta del modod en que tratamos de aprehender el fenómeno que tenemos delante y nos sorprendemos percibiéndolo.
Fig. 9. Turrel, James: Aten Reign, 2013. Luz natural y LED, dimension variable. ( $)$ James Turrell. Instalación: James Turrell, Solomon R. Guggenheim Museum, Nueva York, 21 junio-25 septiembre, 2013. Fotografía: David Heald. $\odot$ Solomon R. Guggenheim Foundation, Nueva York.

exhibited at the 1980 Whitney Museum retrospective in New York. The visitor was immersed in a space where the apparent lack of shape and change in color made people lose balance. Some (visitors) ended up crawling and others even fell down (Turrell. 1992). This is a result of the Ganzfeld effect, which occurs when a person is immersed in an homogeneous and continuous environment (visual, tactile or acoustical) totally surrounded without the possibility of establishing distinct referential elements. The attention given to understand the shape combined with an inability to apprehend the limits of the space, end up in states of altered perception analogous to those produced by sense deprivation. An example would be trying to scrutinize in total darkness. (3)

At the base of the Guggenheim's ramp we at last end up in Aten Reign; (Fig. 9) the most spectacular work of the show. Specifically erected in the main space of Wright's building it occupies the full height of the great void. A series of what seem to be flat surfaces, with decreasing elliptical holes in their centers, fill up the space. Our incapacity to determine the real depth of what we are seeing produces an uneasy feeling. The surfaces appear to be flat but in fact they are not; they are conical sections. The work activates the perceptual mechanisms in order to understand the space but ones senses doubt such awareness because the form can't be clearly understood. So we are very aware our senses working. 
Robert Irwin en el Museo Whitney de Arte Americano. El Museo Withney de Arte Americano de Nueva York expuso entre el 1 de Junio y el 27 de Septiembre la obra Scrim veil-Black Rectangle-Natural Light (Figs. 10, 11) de Robert Irwin, una instalación concebida originalmente en el año 1977 como parte de la gran muestra retrospectiva dedicada entonces al artista. El año que viene, el museo se trasladará al nuevo edificio diseñado por Renzo Piano en el Meat Packing District, en el extremo sur de la antigua línea elevada de tren que abastecía la zona hoy reconvertida en paseo (High Line), junto al rio Hudson en downtown Manhattan. La cesión del actual edificio al Metropolitan, prevista para 2015, hacía de ésta la última oportunidad de ver la obra de Irwin en el lugar para el que fue concebida.

Pese a tratarse aquí de una única obra, las coincidencias entre la anterior exposición y esta invitan a considerarlas de manera conjunta. Además de mostrarse simultáneamente y encontrarse a escasos metros una de otra, Scrim veil-Black Rectangle-Natural Light fue la pieza principal de la retrospectiva que el Withney dedicó a Robert Irwin en su día, como Aten Reign lo fue de la retrospectiva que el Guggenheim dedicaba a Turrell. Las dos obras están

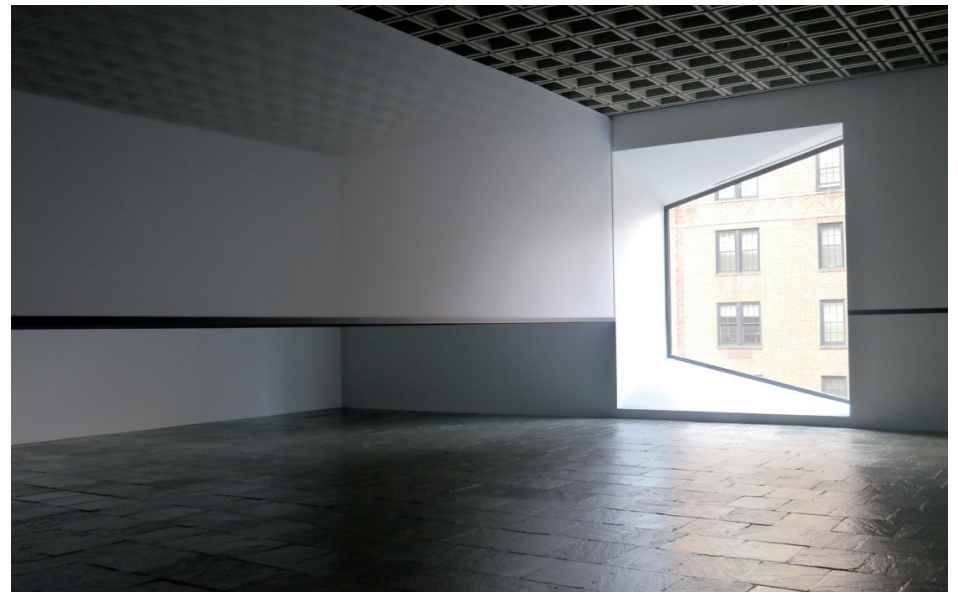

Fig. 10. Irwin, Robert: Scrim veil-Black Rectangle, 1976 y 2013. Tela, metal y madera (144×1368 $\times 49$ pulgadas). Whitney Museum of American Art, Nueva York.

As we move around the ellipse we feel how the space (4) changes. The mental reconstruction is elusive. One's perception strives to understand the suspended artifact over our heads. The apparent surfaces change color gradually according to their depth. Beds placed under it allow us to enjoy the show lying down and gravity seems to vanish. As colors vary the depth also seems to change. James Turrell isolates through abstraction the luminous event. He gets rid of all superfluous expression and builds silences in which we can hear how our sensitive mechanics work. We see light floating in spaces. We realize how we in trying to apprehend the phenomenon in front of us, we are mesmerized and we surprise ourselves watching it.

Robert Irwin at the Whitney Museum of American Art. Between June 10th and September 27th 2013 the New York Whitney Museum of American Art showed Robert Irwin's Scrim veil-Black Rectangle-Natural Light (Figs. 10, 11), an installation originally conceived in 1977 as part of the great retrospective the museum dedicated to the artist back then. Next year the Whitney Museum will be relocated in the new building designed by Renzo Piano in the Meat Packing District, situated near the Southern end of the High Line, the former elevated railroad by the Hudson River converted now to a public park. The planned overtaking of the Breuer building by the Metropolitan in 2015 would make this the last opportunity to see Irwin's work at the place it was meant to be. 
instaladas en los espacios más representativos de dos museos emblemáticos de Manhattan (acabados con siete años de diferencia), con los que mantienen una indisoluble relación por haber sido específicamente concebidas para ser expuestas en ellos y estar completamente condicionadas por los respectivos lugares. Ambos artistas comparten una raíz común: nacidos en California, fueron vinculados al movimiento Light and Space, a finales de los años sesenta, y sus obras remiten a la percepción espacial como argumento principal de la experiencia artística que pretenden desencadenar.

Contaba Irwin en 2007 (5) que en 1977 él no tenía ninguna intención de realizar la retrospectiva programada pues su interés radicaba básicamente en que le dejasen trabajar en el espacio expositivo de la planta superior del edificio que Marcel Breuer había completado en 1966 (Irwin, 2013). Le habían impresionado profundamente las dimensiones de la sala (para tratarse de un espacio expositivo en Manhattan), su llamativo suelo de pizarra y la ventana trapezoidal a la avenida Madison, que denomina socarronamente 'la venganza del arquitecto', (Irwin, 2013) porque su rotunda presencia tiende a interferir con todas las exposiciones que alberga la sala.

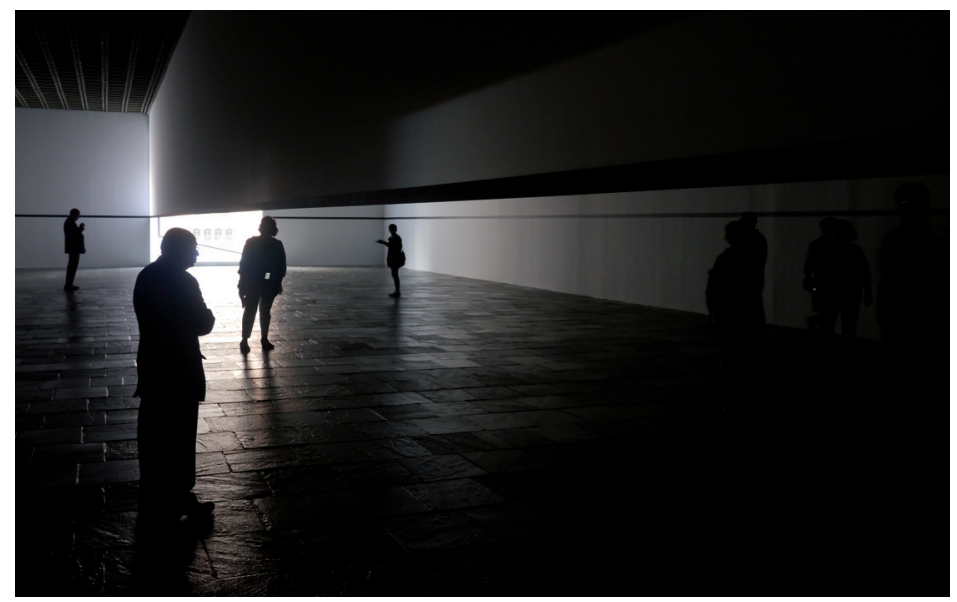

Fig. 11. Irwin, Robert: Scrim veil-Black Rectangle, 1976 y 2013. Tela, metal y madera $(144 \times 1368 \times 49$ pulgadas). Whitney Museum of American Art, Nueva York.

Despite of this being a single piece the coincidences among the Turrell exhibit and this one invite us to consider them together. Not only were they shown simultaneously but also rather near each other. Scrim veil-Black Rectangle-Natural Light was the main work at Irwin's retrospective in the Whitney as Aten Reign was at the Guggenheim. Both of them were installed in the most representative spaces within each of the two most emblematic museums in Manhattan keeping an indissoluble relationship between them; having been specifically conceived for their respective museums and being completely conditioned by their respective spaces. Both artists share a common ground both were born in California, are linked to the Light and Space movement of the late 70's and their works refer to spatial perception as the main focus they seek to trigger as artistic expression.

Irwin has recalled a couple times how in 1977 he had no intention of doing the programmed retrospective and how his interest was working at the exhibition space in the upper floor of the building Marcel Breuer had completed in 1966 (Irwin, 2013). He had been deeply impressed by the size of the room (considering it to be in Manhattan), the dark slate floor and the trapezoidal Madison Avenue window which he sarcastically called "the architect's revenge" (Irwin, 2013) because its strong presence interferes with the shows held in the room. 
Desde 1970, año en que dio por zanjado su trabajo de estudio, Irwin estuvo dedicado fundamentalmente a crear instalaciones para espacios concretos, respondiendo a las condiciones de cada uno de los lugares en los que habría de ubicarse la obra (Site-Conditioned Installations). Scrim veil-Black Rectangle forma parte de dicha investigación y supuso un hito en la carrera del artista, que en aquella época escribió su ensayo, Notes on a Model, (Irwin 1977) justificando la coherencia del desarrollo de un arte condicionado por su entorno, que sirviese como catalizador de la experiencia perceptiva.

En este caso, no hay recorrido que hacer; la instalación aparece al salir del ascensor y nos encontramos de pronto inmersos en la obra, todo el lugar la compone. La primera impresión es una fuerte conciencia de la propia presencia. La súbita irrupción en el enorme espacio de la sala vacía impresiona. No hay límite ni distancia, estamos dentro formando parte de la obra.

Un telón de gasa (6) suspendido divide longitudinalmente la gran sala en la que desembocamos. Está adosado perpendicularmente a la ventana de la fachada oeste. El reflejo de la luz que por ella entra genera un brillo acuoso sobre el suelo de pizarra, que se interpone entre la ventana y nuestra mirada allá donde nos situemos. Toda la estancia resuena. El edificio cobra una presencia antes inad-

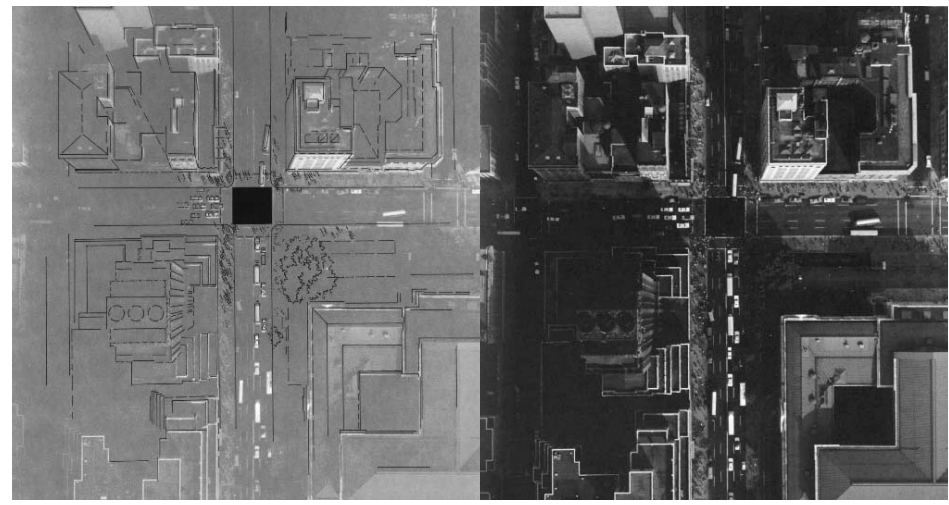

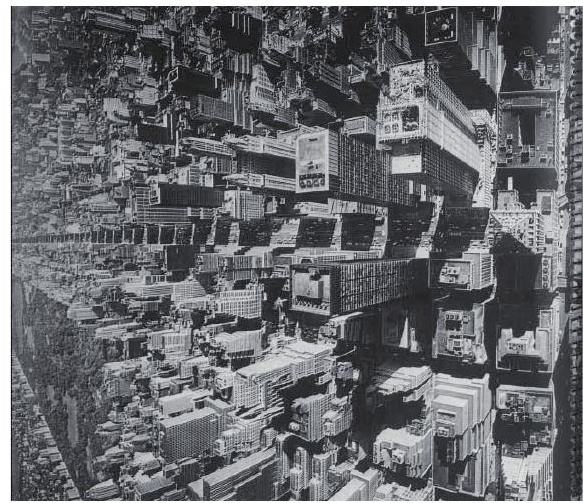

Since 1970 when Irwin considered himself to be done with studio working, he mainly dedicated himself to specific site installations responding to the very conditions of each and every intervention space. Scrim veil-Black Rectangle belongs to that investigation and it was a major breakthrough in the artist's career who by then wrote his essay Notes on a model (Irwin 1977) arguing on the coherence of developing a site-conditional art which would work as a catalyst for the specific perceptive experience.

In this case there is no transition, the installation appears as we get off the elevator and we are all of a sudden immersed in it; the whole space forms it. The first impression is a strong feeling of our own presence. The precipitous eruption into the vast space is impressive. There is no limit, no distance, we are inside the work.

A hanging veil (6) divides lengthways the big room we step into. It is perpendicularly attached to the west façade window. The reflection of the light that arrives through it generates a watery shining on the floor, right between the window and our eye wherever we might be in the room. The entirety of the room reverberates. The building gains a previously unaware presence. From the lower part of the veil hangs a metal black lintel slightly over the height of the eye (Irwin must be tall) that arriving to the walls becomes a black strip and surrounds the whole perimeter. The veil receives the natural light coming in through the room's only opening (the 'revenge'). Depending on which side we look at it the translucency changes. As we move along the space and 
vertida. Del borde inferior de la gasa pende un listón negro de acero, ligeramente por encima de la altura de la vista (Irwin es alto), que al llegar a las paredes se convierte en una línea negra y recorre todo el perímetro de la sala. La gasa recoge la luz natural que entra por el único hueco de la habitación. Según el lado en que nos situemos, se altera su transparencia. A medida que nos movemos por el espacio y miramos en torno nuestro somos conscientes de cómo varían los fenómenos lumínicos que nos rodean. No se trata tan sólo de una obra específicamente concebida para un lugar, sino que las propias características del mismo son las que la determinan. La aparente desnudez de la sala (hubo quien se asomó y se fue pensando que no había nada en ella) pone de manifiesto la imposibilidad del vacío. Siempre se dan en el espacio acontecimientos lumínicos tangibles, siempre hay algo, es una cuestión de atención. La percepción avisada, la consciencia del actuar de los sentidos, el percatarse de la recepción del estímulo es el argumento fundamental de la obra de ambos artistas.

En 1977, además de esta obra, Irwin desarrolló dos intervenciones mucho más arriesgadas fuera del amparo del museo, poniendo en cuestión la legitimidad conferida a la obra por el contenedor; en esta ocasión no han sido reproducidas. Pintó un cuadrado negro sobre la calzada del cruce de la calle 42 y la Quinta Avenida (Fig. 12) y con unas bandas negras, trazó las aristas de
Fig 12. Plano negro, Quinta Avenida y calle 42 Nueva York. Catálogo: Robert Irwin, Whitney Museum of American Art, 18 abril-28 mayo, 1977.

Fig. 13. Fotografía aérea de la Quinta Avenida. Catálogo: Robert Irwin, Whitney Museum of American Art, 18 abril-28 mayo, 1977. Fotografía: Aerographics Corp.

Fig. 14. Rectángulo de líneas, World Trade Center, Nueva York. Catálogo: Robert Irwin, Whitney Museum of American Art, 18 abril-28 mayo, 1977.
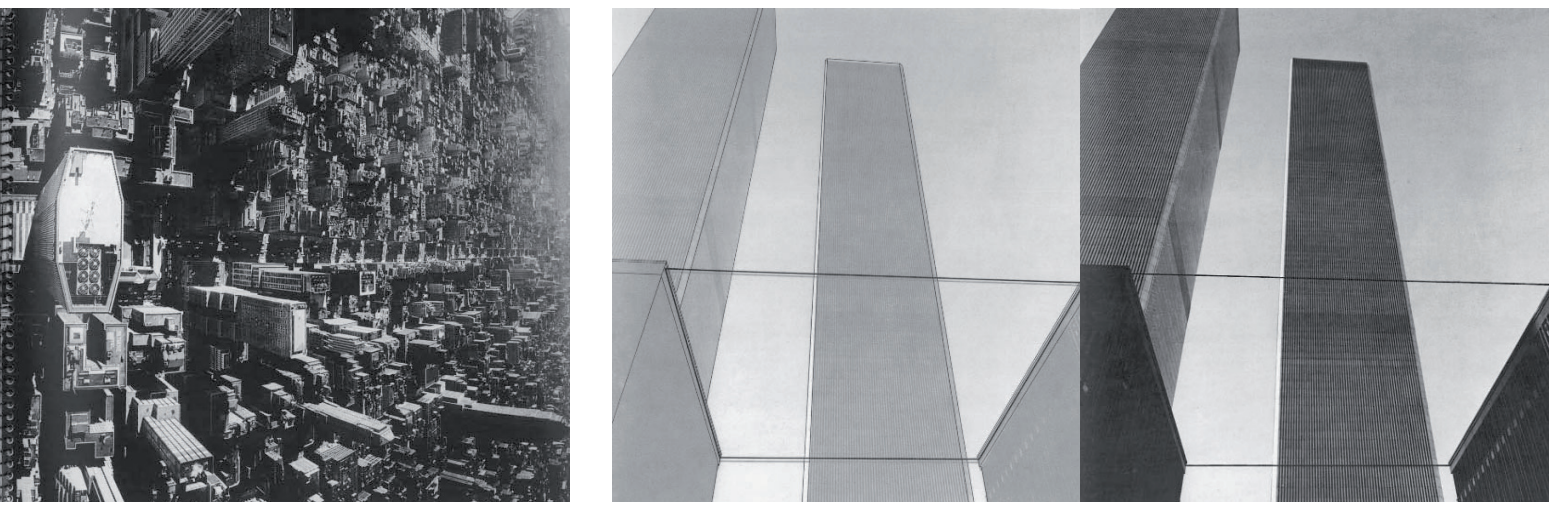

we look around (there weren't too many people) we are aware of how the light phenomena around us vary depending on our position. It isn't just a site conceived installation, the characteristics of the site completely determine it. The apparent emptiness of the room (there were some who thought the place was actually empty!) shows the impossibility of the void, but there are always tangible luminous phenomena within the space, there is always something, it is only a matter of focus. The attentive perception, the conscience of the senses in action, being aware of our body responding to the stimuli is the main issue in both artist's work.

In 1977 apart from this work Irwin developed two other much riskier interventions out of the museum's shelter, questioning the legitimacy the container provides the work in it, they were not reproduced this time. He drew a black square on the street crossing between 42nd street and the Fifth Avenue (Fig. 12) and with some black strips he traced a hanging on the air rectangle between the World Trade Center buildings. The interest of these two proposals lay on their confrontation with a complex urban context which challenged their ability to raise the artistic experience. In the catalogue for Irwin's exhibition in the Whitney we can clearly appreciate Irwin's intention of transcending the museum's exhibition space extending it to the whole Manhattan scope, relating the Black Rectangle space with the other two rectangles, with the light rectangle around Central Park at night and ultimately with the entirety of Manhattan's rectangular street grid which structures the island in an ambitious attempt of making the whole city resound. (Fig. 13) 
un rectángulo suspendido en el aire entre los edificios del desaparecido World Trade Center, (Fig. 13) en el distrito financiero. El interés de ambas propuestas radica en su confrontación con un contexto urbano complejo, que ponía a prueba la capacidad de ambas de suscitar la experiencia artística. En el catálogo que acompañaba a la exposición original podemos apreciar claramente la intención de Irwin de trascender el espacio expositivo del museo, ampliando la experiencia artística a todo el ámbito de Manhattan, relacionando el espacio rectangular de la sala con los dos rectángulos trazados fuera de ella, con el espacio de luz definido por las luces del perímetro de Central Park y en última instancia, con la retícula hipodámica que estructura la isla en un ambicioso intento de hacer resonar toda la ciudad. (Fig. 14)

El interés de Irwin por emplear la obra de arte como elemento transformador de la consciencia de la propia percepción y su interés por llevar la experiencia estética más allá de su marco tradicional había comenzado a radicalizarse a partir de 1970. La retrospectiva supuso un hito que le llevó durante los años siguientes a desarrollar su trabajo en ámbitos muchas veces al margen de las salas de exposición empleando como argumento las condiciones de contorno de los espacios sobre los que intervenía.

La búsqueda de un arte que pusiese de manifiesto las condiciones específicas en las cuales se produce la experiencia estética, más allá del objeto como referente, acercaron a Irwin a posturas muchas veces más cercanas a la arquitectura o al paisajismo que a la producción del objeto artístico al uso. La eliminación del muro de la Galería Malynda Wyatt en Venecia, en 1980; el proyecto para el enriquecimiento artístico del Aeropuerto Internacional de Miami, que lamentablemente no pudo llevarse a cabo a mediados de los ochenta, pero que Irwin calificó como enormemente fructífero; los jardines del Dia Beacon, al norte de Nueva York, junto al Hudson, de 1996; los del propio LACMA, de fecha reciente o el jardín central del Centro Getty de Los Ángeles, del arquitecto Richard Meier, al que tantos años ha dedicado desde el inicio de los noventa son proyectos que surgen de las inquietudes de un artista que empezó pintando cuadros y cuyo afán por comprender la raíz y trascender el marco tradicional en el que se confinaba su disciplina le fueron

Irwin's interest on using art work as a transforming device for the conscience of perception and his interest on taking the esthetic experience beyond its traditional framing began to radicalize by 1970 . The retrospective was a landmark event and afterwards he started to develop his work in sites many times far from the usual exhibition rooms using the site conditions he was to work with in as the main substance of his art.

The search for an art that would manifest the site specific conditions in which the esthetic experience takes place, beyond the object as a reference, took Irwin towards a position many times closer to producing architecture or landscape design rather than the usual art as object. The wall removal at the Malynda Wyatt Gallery in Venice in 1980, the artistic enrichment project for the Miami International Airport, unfortunately abandoned in the mid-eighties after what Irwin considered to be a very enriching experience, the Dia: Beacon gardens upstate New York by the Hudson (1996), the LACMA gardens or the Richard Meier's Getty Center gardens are projects that arise from an artist's concerns with specific situations. He started painting and his ambition to understand the roots of his own art from a conceptual point of view and transcending its traditional frame took him to positions very close to architecture as he was trying to give a specific esthetic response to each situation. 
deslizando, al tratar de dar una respuesta estética específica a cada situación, hacia posturas muy próximas a la arquitectura.

Tanto las obras de Turrell como las de Irwin pretenden suscitar en quien las contempla o habita la consciencia de los propios sentidos, para en última instancia instigar la reflexión acerca de nuestra manera de percibir el mundo. La experiencia estética en ambos casos aspira a despertar conciencias. La profunda raíz conceptual que comparten en sus obras tuvo un curioso capítulo en común hace cuarenta y cinco años, que les llevó a experimentar juntos su propia capacidad sensorial y sus efectos sobre la consciencia y la percepción. (7) Su invocación puede clarificar posturas y revelar unas ideas postuladas entonces como declaración de intenciones, que no han perdido un ápice de vigencia en la obra de ninguno de los dos a lo largo de los años.

Los Ángeles, 1968-1969. A finales de 1968, cuando ambos formaban parte del incipiente movimiento Light and Space que se desarrollaba en California, Robert Irwin invitó a James Turrell a participar en el programa Art and Technology Collaboration impulsado por el comisario del Museo de Arte del Condado de los Ángeles (LACMA), Maurice Tuchman. Artistas como Andy Warhol, Tony Smith, Claes Oldenburg o Jean Dubuffet entre otros, (8) fueron puestos en contacto con diversas empresas (Container Corporation of America, Walt Disney Enterprises y otras) para desarrollar proyectos conjuntos. Los resultados se expusieron en 1971, en el LACMA.

El libro Notes Toward a Conditional Art, editado en 2011 por el Museo J. Paul Getty de Los Ángeles, que recopila los escritos de Irwin recoge parte de la documentación elaborada por el equipo que formaron en noviembre de 1968 Robert Irwin y James Turrell, junto a Edward Wortz, doctor en medicina aeroespacial de la Garret Aerospace Corporation, (Fig. 15) una subcontrata de la NASA que trabajaba para el programa Apollo, que por entonces, preparaba el primer viaje tripulado a la luna. Su objetivo era investigar qué grado de conciencia perceptiva sería necesario para garantizar la orientación y la estabilidad mental de los astronautas, de cara a mantener la consciencia básica en las misiones espaciales. Equipados con una cámara anecoica, una esfera

Both Turrell's and Irwin's works try to provoke in the observer or inhabitant the awareness of his own senses in order to ultimately instigate consideration on how we perceive the world. The esthetic experience in both cases aspires to awaken the conscience. The deep conceptual root they share in their works have a curiously mutual chapter some forty five years ago which lead them to experiment together their own sensorial capability and its effects on conscience and perception. (7) To bring that chapter back can clarify their positions and reveal some ideas postulated then as common declarations of intention which have retained their validity in each of their the works through all these years.

Los Ángeles 1968-1969. By the end of 1968, when they both were engaged in the southern California Light and Space movement, Robert Irwin invited James Turrell to participate in the Art and Technology Collaboration Program curated by Maurice Tuchman from the Los Angeles County Museum of Art. Artists like Andy Warhol, Tony Smith, Claes Oldenburg or Jean Dubuffet among others (8) were set together with different American companies (Walt Disney, Container Corporation of America...) to develop projects together. The results were shown at the LACMA in 1971.

The book Notes Toward a Conditional Art edited in 2011 by the Los Angeles J. Paul Getty Museum compiles part of the documents produced by the team Robert Irwin, James Turrell and Doctor in Aerospace Medicine Edward Wortz from the 
Ganz-field (9) -semiesfera de plástico translúcido homogéneamente iluminada- y una máquina de electroencefalogramas (EEG) llevaron a cabo diversos experimentos diseñados para poner a prueba la percepción sensorial en la Universidad de UCLA, con la colaboración de algunos alumnos.

El interés de aquel encuentro radica en el método pragmático mediante el cual determinadas ideas relacionadas con la fenomenología de la percepción se pusieron a prueba, mediante experimentos diseñados por el equipo con un doble objetivo artístico-científico. La declaración de intenciones inicial, que se abría con una cita de Merleau-Ponty, decía lo siguiente: "El pensamiento objetivo ignora el sujeto de la percepción. Ello es debido a que se da a sí mismo el mundo ya hecho, como medio contextual de todo posible acontecimiento, y trata la percepción como uno de estos acontecimientos". "Hemos comenzado nuestro trabajo asumiendo el precepto de que el arte no es un objeto, es experiencia; en cada caso, una experiencia particular definida por el artista. Aunque la mayoría del arte depende de un objeto para conducir o mediar la experiencia, ésta es una condición que hemos buscado alterar, escogiendo el ámbito de la percepción

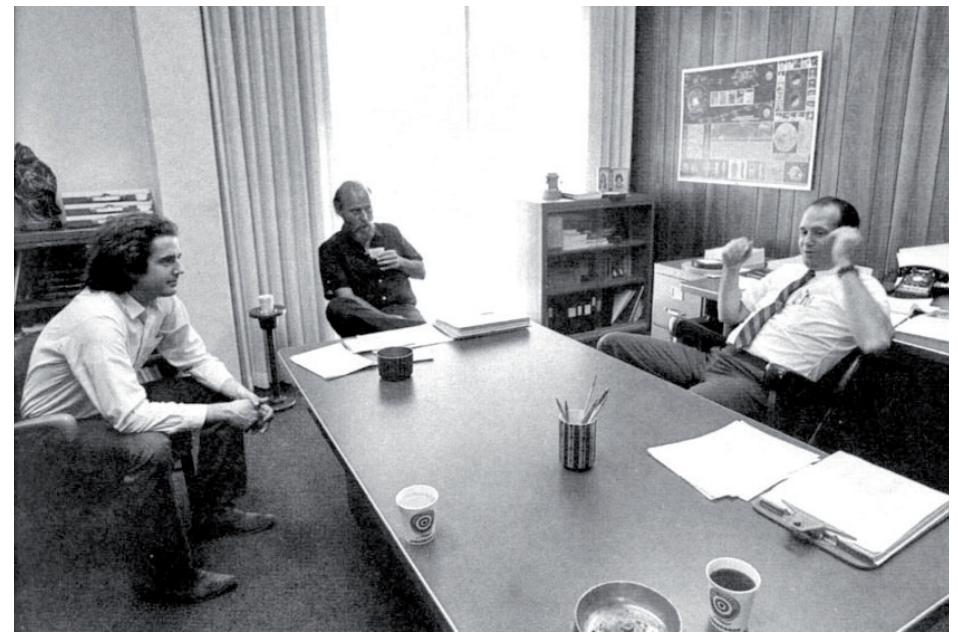

Fig. 15. Robert Irwin, James Turrell y el doctor Edward Wortz conversando en la Garret Corporation, Los Ángeles, California, 1969. Fotografía: Malcolm Lubliner.

Garret aerospace Corporation (Fig. 15) a company subcontracted by NASA to work on the Apollo Program which by then was preparing the first manned flight to the moon. Their aim was to investigate what degree of perceptive conscience was necessary to guarantee orientation and mental stability of the astronauts in order to maintain basic consciousness during space missions. Provided with an anechoic chamber, a Ganzfeld sphere (9) (translucent hemisphere homogeneously illuminated), and an electroencephalogram (EEG) machine they carried out different experiments designed to test sensorial perception in UCLA with the help of some students.

The interest of that meeting lies with the pragmatic method through which certain ideas related to the phenomenology of perception were tried out in experiments designed by the team with a dual artistic/scientific purpose. The initial intentions declaration opened up with a Merleau-Ponty quoting as follows: "Objective thought is unaware of the subject of perception. This is because it presents itself with the ready-made world as the setting of every possible event and treats perception as one of these events". "We have begun our Project with the precept that art is not object-it is experience-in each case a particular experience defined by the artist. Although much/most art depends on an object to convey or mediate the experience, this is a condition we have sought to alter by choosing the realm of perception as our art form. Our involvement has led us to define a non-objective situation, one that would be unmediated by object, objective thought or structure or verbal-literal description, 
como nuestra forma de arte. Nuestra implicación nos ha llevado a definir una situación no objetiva, una en la que no mediaría objeto, pensamiento objetivo o estructura o descripción verbal-literal, estableciendo límites perceptivos singulares para crear una experiencia única. Al hacerlo pretendemos provocar al individuo una consciencia de la percepción, haciendo del sentido de los sentidos la experiencia de la realidad. Al construir formas singulares para la percepción esperamos que los mecanismos de la percepción puedan ser percibidos por cada persona, el despertar de algo que ya estaba ahí’. (Irwin, 2011)

Así pues su objetivo era dilucidar cómo inducir respuestas específicas activando determinados mecanismos perceptivos. Desarrollaron durante casi ocho meses diversas pruebas que, en su mayoría, se llevaron a cabo en la cámara anecoica, alterando las condiciones lumínicas (luces estroboscópicas, oscuridad, niveles ínfimos de luz ) y acústicas (campos sónicos totales, silencios, cambios de volumen...), aislando al individuo del contexto y confrontándolo con la percepción de sus propias mecánicas corporales (respiración, latidos del corazón...) o introduciendo estímulos controlados y tratando de baremar sus efectos. Experimentaron durante varios meses en ella. Lawrence Weschler, en la biografía de Irwin Ver es olvidar el nombre de las cosas que uno ve-cita atribuida a Paul Valery (Weschler, 1982- cuenta cómo de manera extrema llegaron a permanecer en su interior (Fig. 16) hasta seis u ocho horas seguidas a oscuras, tras lo cual se producía al salir de ella una vívida percepción fruto del estado de aislamiento sensorial previo. La permanencia en la cámara aguzaba los sentidos. (Weschler, 1982) "Lo que la cámara nos ayudaba a ver eran la extrema complejidad y la riqueza de nuestro mecanismo sensorial y lo poco que usamos de él la mayoría del tiempo".

Se realizaron excepcionalmente otras pruebas, como tratar de cuantificar los efectos de la meditación midiendo las ondas alfa (alpha conditioning) del cerebro en los EEG y el efecto que objetos culturales como la palabra tenían sobre las ondas cerebrales, mediante la evocación verbal de espacios. Los experimentos y la colaboración se prolongaron hasta agosto de 1969, un mes después del alunizaje. (10) Entonces, Turrell abandonó abruptamente el equipo dando por finalizada su colaboración con Irwin. Al ser pregunta-

thus setting up unique [scratched out: extreme] boundaries of perception to create a unique experience. In doing such, we intend to bring to the individual an awareness of perception -making the sense of the senses the experience- the reality. In building forms unique to perception we hope to awakening to something which was always already there". (Irwin 2011)

So their intention was to elucidate how to induce specific responses by activating certain perceptual mechanisms. They developed different experiments during eight months which were mainly carried out in the anechoic chamber by altering the light (stroboscopic lights, darkness, dim and color lights...) and acoustic conditions (total sonic fields, silences, volume changes...) isolating the individual from the environment and confronting him with the perception of his/her own mechanics (breathing, heartbeats...) or creating other controlled stimuli and trying to measure their effects. They used it during several months. Lawrence Weschler in Irwin's biography "Seeing is forgetting the name of the thing one sees" (quote attributed to Paul Valery (Weschler, 1982)) tells how they carried out extreme experiences by staying in the chamber (Fig. 16) for over six or eight hours continuously.

After these experiments they gained hyper sensitive and vivid perception due completely from the previous sensory deprivations. Staying in the chamber sharpened their senses. (Weschler, 1982) "What the anechoic chamber was helping us 
do años más tarde por aquello, restó importancia a la investigación arguyendo la imposibilidad de transmitirla, salvo reproduciendo las complejas condiciones de contorno, lo cual queda patente en las abstrusas notas que trataban de describir la experiencia perceptiva de la cámara anecoica. Sin embargo, reconoció la importancia de la experiencia a título personal. La imposibilidad de la reproducción era algo con lo que Irwin ya había lidiado unos meses antes, cuando sus inquietudes le habían llevado a plantear de manera radical la naturaleza de su obra (11) llegando a negarse a que fuese publicada por considerar que se desvirtuaba. El tipo de obra que ambos proponen sólo posee autenticidad (12) cuando se está en ella, puesto que su mera representación carece de la capacidad de activar los sentidos en la que esencialmente se funda.

El carácter empírico de aquella experiencia engarza con un cierto pragmatismo que podemos encontrar en la obra de ambos, cuyos artefactos perceptivos o lentes fenoménicas, como los denomina Steven Holl, son de una gran efectividad gracias al ensayo directo y ajuste a lo largo de años. La austeridad formal de su obra es fruto de la depuración necesaria para la percepción unívoca que se pretende crear, obedeciendo en gran medida a motivos prácticos más que a un afán minimalista.

En la obra de James Turrell, la constante búsqueda del deleite estético y de lo sublime a través de la introspección sensorial le ha llevado a desarrollar toda una serie de recursos de interpelación visual que actúan de manera prácticamente mecánica, sumergiendo al perceptor en un campo visual específico. $\mathrm{Su}$ obra sin embargo posee un alto contenido poético: el empleo de la luz como sustancia y sus poderosas connotaciones simbólicas permiten incontables evocaciones dentro del mundo del arte, incluida la pintura. Por otro lado, los Skyspaces engarzan con la ancestral tradición de los observatorios celestes, cuya memoria se remonta al propio origen de la arquitectura. Pese a ello, su obra no opera mediante el recuerdo o el simbolismo. La evocación poética del espacio de la memoria no es posible en las obras de Turrell. La depuración formal contribuye a la abstracción remitiéndonos a un lugar fuera del tiempo que carece de textura.

to see was the extreme complexity and richness of our sense mechanism and how little of it we use most of the time". They accomplished other experiments as trying to quantify the effects of meditation by measuring the alpha rays in the EEG and the effects of cultural objects like words over mental waves by invoking spaces. The collaboration went through up to August 1969, one month after the moon landing. (10) Then Turrell suddenly abandoned the team considering his relation with Irwin over. Being asked some years later he downplayed the research explaining how the things they found out didn't apply to anyone else unless they could come to them the same way. This shows in the cryptic notes that come out of the experiments when trying to translate the anechoic chamber perceptive experience into words. Though it, he did recognize the importance of the work at a personal level. The impossibility of reproduction was something Irwin himself had come across a few months before when his concern about the radical nature of his art (11) had led him to forbid any reproduction of his work saying it would compromise the work. The kind of work they both propose is only authentic (12) when directly confronted or directly within it because its mere representation lacks the capability of activating the senses which is what the works are all about.

The empirical character of that experience relates to a certain pragmatism we can find in both of them. Their perceptual artifacts or phenomenal lenses as Steven Holl calls them are very efficient because of their direct testing and adjusting over the years. Formal austerity in their work is a matter of a necessary purification for the univocal response pursued, obeying practical issues much more than an intentional minimalism. 
En el caso de Robert Irwin, la inmersión en la experiencia perceptiva tal vez requiera una mayor complicidad por parte de quien acude a ella. (13) Irwin presenta una actitud más radical, en la que el cuestionamiento del propio concepto de obra de arte se encuentra, en gran medida, en la raíz de su trabajo. Esta postura expuesta a menudo en los textos que acompañan sus exposiciones, acercándolo a los artistas conceptuales, y su afán por trascender los límites tradicionales en los que habitualmente se confina la obra de arte, le han llevado a desarrollar un discurso más abierto, en el que la búsqueda de resonancias en entornos de índole muy diversa han acabado por conferir a su trayectoria un carácter más ecléctico.

Ambos artistas despliegan una serie de fértiles recursos e ideas vinculados a la fenomenología de la percepción, que nos remiten a esa compleja intersección en la que la arquitectura opera como instrumento para ampliar y enriquecer nuestra visión del mundo a través de los sentidos.

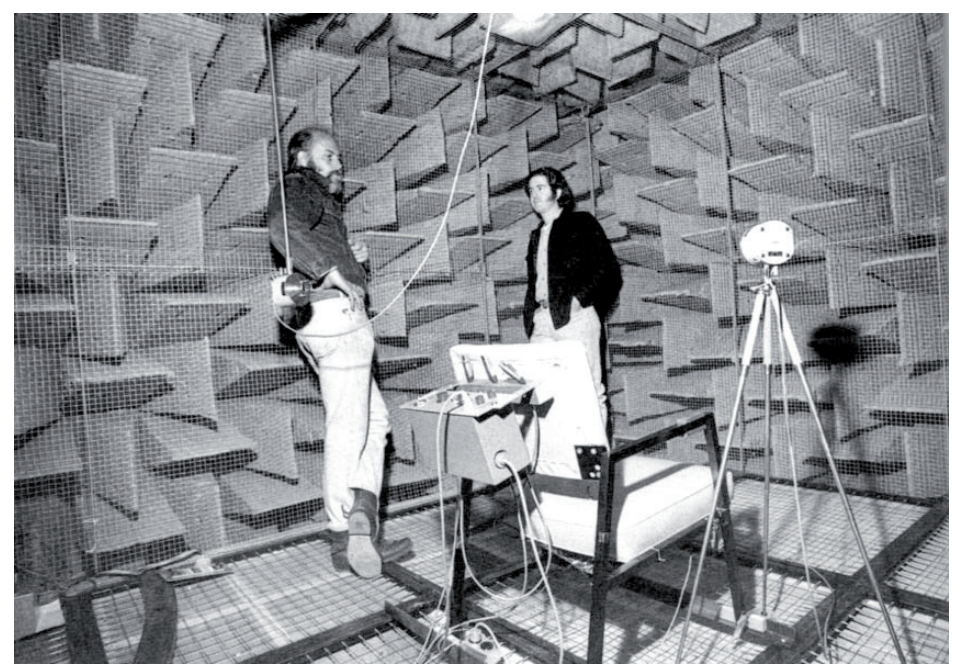

Fig.16. Robert Irwin y James Turrell en la cámara anecoica, UCLA, California, 1969. Fotografía: Malcolm Lubliner.

In James Turrell's work the permanent search for esthetic delight and the sublime through sensory introspection has led him to develop a whole series of visual resources which act almost mechanically immersing the perceiver in a specific visual field, despite of which his work has a deep poetic content: using light as a substance has very powerful symbolic connotations and allows for endless relations within the art scope, painting included. On the other hand the Skyspaces relate to the ancestral tradition of stellar observatories which go back in time to the very origin of architecture itself (Stonehenge). The poetic evocation of a literal space is not possible in Turrell's works. The formal purification contributes to an abstraction setting us in a place out of time without texture.

In the case of Robert Irwin the perceptual experience immersion might require a higher degree of compromise from the audience. (13) Irwin presents a more radical attitude where the conceptual questioning of the very art work might be the main focus. This position, frequently exposed in his texts, places him with conceptual artists, and his ambition for transcending the traditional settings of the art work have brought him to develop a more open discourse, in which the search for resonance in diverse environments has come to give his career a more eclectic character. Both artists deploy a series of inspiring resources and ideas related to the phenomenology of perception which send us to the complex intersection in which architecture operates as an instrument amplifying and enriching our vision of the world through the specificity of the senses. 


\section{BIBLIOGRAFÍA}

ADCOCK, Craig. James Turrell, The Art of Light and Space. Berkeley-Los Angeles-Londres: University of California Press, 1990.

AA.VV. James Turrell: Sensing Space. University of Washington, Seattle: Henry Art Gallery, 1992.

AA.VV. James Turrell. Fundación NMAC, Edizione Charta srl Milan.

AA.VV. Robert Irwin, Primaries and secondaries. California: Museum of Contemporary Art San Diego, 2008.

BENJAMÍN, Walter. La obra de arte en la época de su reproductibilidad técnica. Traducción: WEIKERT, Andrés E. México DF: Ed. Itaca, 2003.

IRWIN, Robert. Robert Irwin. Notes Toward a Conditional Art.J. Paul Getty Museum, Los Ángeles: Getty Publications, 2011.

IRWIN, Robert; DE SALVO, Donna. Robert Irwin in Conversation with Donna De Salvo. [Video de la conferencia] Museo Whitney de Arte Americano. 25 de julio, 2013. 1h 10min 57sg. http://whitney.org/Exhibitions/RobertIrwin

MERLEAU-PONTY Maurice. '2a Parte. El mundo percibido'. Fenomenología de la percepción. 223 p. Barcelona: Editorial Planeta-De Agostini, 1985.

TURRELL, James. 'La fisicidad de la luz'. CIRCO Boletín técnico. n.117, (Madrid, 2004).

TURRELL, James; et al. James Turrell [Video Transcript] Solomon R. Guggenheim Museum, Nueva York. 21 de Junio - 25 de Septiembre, 2013. 8 min 31sg. http://www.guggenheim.org/new-york/exhibitions/past/exhibit/4819

WESCHLER, Lawrence. Seeing is forgetting the name of the thing one sees. A life of contemporary artist Robert Irwin. Berkeley-Los Ángeles-Londres: University of California Press, 1982.

WESCHLER, Lawrence. Lawrence Weschler on Robert Irwin. [Video de la conferencia] Museo Whitney de Arte Americano. July 11, 2013. 1h $11 \mathrm{~min} 07 \mathrm{sg}$ http://whitney.org/Exhibitions/RobertIrwin

\section{BIBLIOGRAPHY}

ADCOCK, Craig. James Turrell, The Art of Light and Space. Berkeley-Los Angeles-London: University of California Press, 1990.

AA.VV. James Turrell: Sensing Space. University of Washington, Seattle: Henry Art Gallery, 1992.

AA.VV. James Turrell. Fundación NMAC, Edizione Charta srl Milan.

AA.VV. Robert Irwin, Primaries and secondaries. California: Museum of Contemporary Art San Diego, 2008.

BENJAMÍN, Walter. La obra de arte en la época de su reproductibilidad técnica. Traducción: WEIKERT, Andrés E. Mexico DF: Ed. Itaca, 2003.

IRWIN, Robert. Robert Irwin. Notes Toward a Conditional Art.J. Paul Getty Museum, Los Ángeles: Getty Publications, 2011.

IRWIN, Robert; DE SALVO, Donna. Robert Irwin in Conversation with Donna De Salvo. [Video Transcript] Museo Whitney de Arte Americano. 25 de julio, 2013. 1h 10min 57sg. http://whitney.org/Exhibitions/RobertIrwin

MERLEAU-PONTY Maurice. '2a Parte. El mundo percibido' Fenomenología de la percepción. 223 p. Barcelona: Editorial Planeta-De Agostini, 1985. TURRELL, James. 'La fisicidad de la luz'. CIRCO Boletín técnico. n.117, (Madrid, 2004).

TURRELL, James; et al. James Turrell [Video Transcript] Solomon R. Guggenheim Museum, Nueva York. 21 de Junio - 25 de Septiembre, 2013. 8min 31sg. http://www.guggenheim.org/new-york/exhibitions/past/exhibit/4819

WESCHLER, Lawrence. Seeing is forgetting the name of the thing one sees. A life of contemporary artist Robert Irwin. Berkeley-Los Ángeles-London: University of California Press, 1982.

WESCHLER, Lawrence. Lawrence Weschler on Robert Irwin. [Video Transcript] Museo Whitney de Arte Americano. July 11, 2013. $1 \mathrm{~h} 11 \mathrm{~min} 07 \mathrm{sg}$. http://whitney.org/Exhibitions/RobertIrwin

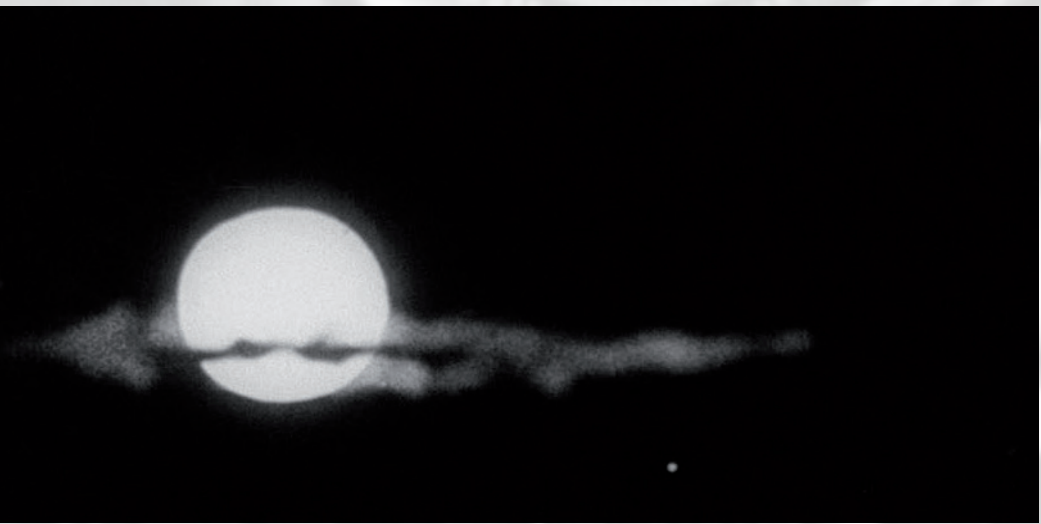

\section{II} un OJO ve [...] 
